\title{
G-CSF and Neutrophils Are Nonredundant Mediators of Murine Experimental Autoimmune Uveoretinitis
}

\author{
Gabrielle L. Goldberg, ${ }^{*}$ Ann L. Cornish, ${ }^{*}$ Jane Murphy, ${ }^{*}$ Ee Shan Pang, ${ }^{*}$ Lyndell L. Lim, ${ }^{\dagger}$ Ian K. Campbell, \\ Karen Scalzo-Inguanti, Xiangting Chen, ${ }^{\S}$ Paul G. McMenamin, ${ }^{\S}$ Eugene Maraskovsky, Brent S. McKenzie, and Ian P. Wicks ${ }^{\star} \|_{\|}$
}

\begin{abstract}
From the Department of Medical Biology,* The Walter and Eliza Hall Institute of Medical Research, University of Melbourne, Parkville, Victoria; the Centre for Eye Research Australia, ${ }^{\dagger}$ University of Melbourne, Royal Victorian Eye and Ear Hospital, East Melbourne, Victoria; the CSL Limited ${ }^{\ddagger}$ Bio21 Institute, Parkville, Victoria; the Department of Anatomy and Developmental Biology, ${ }^{\S}$ School of Biomedical Sciences, Monash University, Clayton, Victoria; the Department of Rheumatology, "Royal Melbourne Hospital, Parkville, Victoria; and the Department of Medicine," University of Melbourne, Parkville, Victoria, Australia
\end{abstract}

Accepted for publication

September 24, 2015.

Address correspondence to Ian P. Wicks, Ph.D., Walter and Eliza Hall Institute of Medical Research, 1G Royal Parade, Parkville, VIC 3052, Australia. E-mail: wicks@ wehi.edu.au.

\begin{abstract}
Granulocyte colony-stimulating factor (G-CSF) is a regulator of neutrophil production, function, and survival. Herein, we investigated the role of G-CSF in a murine model of human uveitisexperimental autoimmune uveoretinitis. Experimental autoimmune uveoretinitis was dramatically reduced in G-CSF-deficient mice and in anti-G-CSF monoclonal antibody-treated, wild-type (WT) mice. Flow cytometric analysis of the ocular infiltrate in WT mice with experimental autoimmune uveoretinitis showed a mixed population, comprising neutrophils, macrophages, and T cells. The eyes of G-CSF-deficient and anti-G-CSF monoclonal antibody-treated WT mice had minimal neutrophil infiltrate, but no change in other myeloid-derived inflammatory cells. Antigen-specific T-cell responses were maintained, but the differentiation of pathogenic type 17 helper T cells in experimental autoimmune uveoretinitis was reduced with G-CSF deficiency. We show that G-CSF controls the ocular neutrophil infiltrate by modulating the expression of $\mathrm{C}-\mathrm{X}-\mathrm{C}$ chemokine receptors 2 and 4 on peripheral blood neutrophils, as well as actin polymerization and migration. These data reveal an integral role for G-CSF-driven neutrophil responses in ocular autoimmunity, operating within and outside of the bone marrow, and also identify G-CSF as a potential therapeutic target in the treatment of human uveoretinitis. (Am J Pathol 2016, 186: 172-184; http://dx.doi.org/ 10.1016/j.ajpath.2015.09.008)
\end{abstract}

Uveitis is a leading cause of blindness in developed countries. Intermediate/posterior uveoretinitis damages the retina and accounts for most visual morbidity. Infections cause approximately $50 \%$ of uveitis cases, ${ }^{1}$ but the remainder are believed to be autoimmune. ${ }^{2}$ Although current therapies control autoimmune uveitis in many patients, some fail to respond, or treatment is limited by adverse effects. There is consequently a need for alternative therapeutic approaches. Experimental autoimmune uveoretinitis (EAU), a widely used murine model of noninfectious posterior uveoretinitis, is $\mathrm{CD}^{+}{ }^{+} \mathrm{T}$-cell-mediated and mimics the clinical and histopathological features of human disease. ${ }^{3}$ Type 1 helper $\mathrm{T}$ (Th1) cells contribute to EAU, but recent studies suggest
Supported by The Ophthalmic Research Institute of Australia, CSL Limited and Reid Charitable Trusts, The National Health and Medical Research Council (Canberra, Australia), Career Development Fellowship grant 1034598 (G.L.G.), Peter Doherty Post-Doctoral Fellowship grant 310608 (A.L.C.), Industry Research Fellowship grant 461287 (I.K.C.), Clinical Practitioner Fellowship grant 1023407 (I.P.W.), program grant 1016647 (I.P.W.), and operational infrastructure grants through the Australian Government Institute for Research and Innovation in Social Services and the Victorian State Government Offer Information Statement.

Disclosures: CSL limited has a commercial interest in the development of cytokine antagonists and provided partial funding for the project. I.K.C., K.S.-I., B.S.M., and E.M. are employees of CSL limited, own stock, and/or have stock options in CSL limited. I.P.W. and I.K.C. are inventors on a patent covering granulocyte colony-stimulating factor antagonism that has been licensed to CSL limited. 
that Th17 cells (but not IL-17 itself) and IL-23, a potent stimulator of Th17 cell differentiation, are nonredundant in this disease model. ${ }^{4}$ In contrast, although innate immune cells, including neutrophils and macrophages, feature prominently in the ocular infiltrate in EAU, ${ }^{5,6}$ the pathogenic role of myeloid cells, or regulators of myeloid cell production and function, has been far less studied.

Granulocyte colony-stimulating factor (G-CSF) is a major regulator of steady-state neutrophil production and survival, ${ }^{7}$ and granulopoiesis is reduced in G-CSF- and G-CSF receptor (G-CSF-R)-deficient mice. During infection or inflammation, neutrophil production and export increases, under the influence of G-CSF, in a response known as emergency granulopoiesis. ${ }^{8}$ G-CSF can be produced by multiple cells throughout the body, including macrophages, bone marrow (BM) stromal cells, and endothelial cells. ${ }^{9-11}$ Homeostatic regulation of the neutrophil pool is complex, with proposed feedback mechanisms related to clearance of apoptotic neutrophils in BM, spleen, liver, and mucosal sites. ${ }^{12}$ Regulation of C-X-C chemokine receptors (CXCRs) 2 and 4 and their ligands is critical to neutrophil retention and release from the BM. ${ }^{13}$ CXCR4-deficient mice exhibit constitutive neutrophil mobilization. ${ }^{13}$ Myelokathexis, a congenital cause of human neutropenia, is caused by a gainof-function mutation in CXCR4, increasing BM neutrophil retention. ${ }^{14}$ CXCR2 is also necessary for neutrophil mobilization, ${ }^{15}$ and CXCR2-deficient neutrophils are selectively retained in the BM. G-CSF regulates CXCR2 and CXCR4 expression on BM neutrophils ${ }^{13}$ and increases production of chemokines CXCL1 (mediated via thrombopoietin) and CXCL2. ${ }^{16,17}$ Conversely, G-CSF administration reduces CXCR4 and CXCL12 expression in the BM. ${ }^{13}$

G-CSF also influences neutrophil function outside of the BM compartment. Neutrophil phagocytosis and oxidative burst are increased by G-CSF, ${ }^{18}$ as is neutrophil survival, the latter mediated by induction of Mcl-1 or A1. ${ }^{19}$ G-CSF enhances migration into peripheral tissues via induction of CXCR2 ligands. ${ }^{20}$ G-CSF up-regulates expression of integrins, such as CD11b/CD18, promoting adhesion and transmigration, ${ }^{21}$ and stimulates glycosylation of myeloperoxidase (MPO), converting MPO to a cell surface ligand for E-selectin. ${ }^{22}$ Serum G-CSF is elevated during infection and in sterile inflammatory conditions, ${ }^{8,23,24}$ and G-CSF and G-CSF-R are elevated in the ocular tissue and blood of patients with uveitis. ${ }^{24}$ In patients with active Behçet's disease, peripheral blood (PB) mononuclear cell G-CSF mRNA, CXCR2 expression on circulating neutrophils, and serum CXCL1/growth-regulated oncogene $\alpha(\mathrm{GRO} \alpha)$ increase. $^{25-28}$ The neutrophil chemoattractant CXCL8/IL-8 also increases in uveitis patients. ${ }^{27,28}$ Administration of G-CSF to patients can induce or exacerbate preexisting inflammatory conditions, including uveitis. $^{29,30}$

We have previously reported that G-CSF-deficient mice are resistant to collagen-induced arthritis. ${ }^{31}$ Wild-type (WT) mice treated with anti-G-CSF also had reduced collagen- induced arthritis, even when anti-G-CSF was administered therapeutically. ${ }^{31}$ In this study, we investigated the role of endogenous G-CSF and neutrophils in EAU. Our data show a strong relationship between neutrophilia and elevated G-CSF in PB, and in the eye, in WT mice. In contrast, G-CSF-deficient mice did not develop EAUassociated neutrophilia and were markedly protected from disease, as were WT mice treated with a neutralizing anti-G-CSF monoclonal antibody (mAb; anti-G-CSF). Analysis of the ocular infiltrate revealed a neutrophil-rich infiltrate in WT mice with EAU, which was almost absent in G-CSF-deficient mice and in WT mice treated with anti-G-CSF. Furthermore, expression of CXCR2 on circulating neutrophils was markedly decreased in G-CSF-deficient mice and anti-G-CSF-treated mice with EAU. Lower CXCR2 expression was associated with reduced neutrophil actin polymerization and reduced in vitro and in vivo neutrophil migration. Intriguingly, decreased activation of the neutrophil compartment impaired the differentiation of pathogenic Th17 cells, linking innate and adaptive immunity. These results reveal a fundamental contribution of endogenous G-CSF and neutrophils to the pathogenesis of EAU.

\section{Materials and Methods}

Mice

Experiments were performed in accordance with National Health and Medical Research Council of Australia guidelines and approved by the Animal Ethics Committee of the Walter and Eliza Hall Institute (WEHI; Parkville, VIC, Australia). C57BL/6 mice were obtained from WEHI. G-

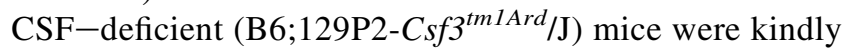
provided by Ashley Dunn (Ludwig Institute for Cancer Research, Parkville, VIC, Australia), ${ }^{32}$ and G-CSF-Rdeficient [B6.129X1(Cg)-Csf3r $r^{\text {tmlLink } / J] ~ m i c e ~ w e r e ~ k i n d l y ~}$ provided by Daniel Link (Washington University Medical School, St. Louis, MO) ${ }^{33}$ C57BL/6 RAR-related orphan receptor (ROR) $\gamma \mathrm{T}$-enhanced green fluorescence protein (eGFP) mice were kindly provided by Gabrielle Belz, and the G-CSF-deficient/ROR $\gamma$ T-eGFP mice were bred at WEHI by crossing the G-CSF-deficient mouse (B6;129P2-Csf3 $3^{\text {tm 1Ard } / J) ~ w i t h ~ t h e ~ C 57 B L / 6 ~ R O R ~} \gamma \mathrm{T}$-eGFP reporter mice. G-CSF-deficient and G-CSF-R-deficient mice were backcrossed onto the C57BL/6 background for $>20$ and $>8$ generations, respectively. LysM-cre-eGFP mice were kindly provided by Michael Hickey (Monash University, Clayton, VIC, Australia) and did not carry the $\mathrm{rd} 8$ mutation in the $\mathrm{Crbl}$ gene. ${ }^{34}$ Mice were housed under standard conditions in the WEHI animal facility.

\section{Induction of EAU}

Unless otherwise stated, EAU was induced as described previously. ${ }^{35}$ Each mouse received $150 \mu \mathrm{g}$ interphotoreceptor 
retinoid-binding protein (IRBP), $250 \mu \mathrm{g}$ Mycobacterium tuberculosis in complete Freund's adjuvant, given by s.c. injection, and $0.5 \mu \mathrm{g}$ pertussis toxin i.p. In some experiments, complete Freund's adjuvant was replaced by incomplete Freund's adjuvant (IFA).

\section{G-CSF Enzyme-Linked Immunosorbent Assay}

Rat anti-G-CSF mAb (clone 67604) and biotinylated rabbit anti-G-CSF polyclonal Ab (R\&D Systems, Minneapolis, $\mathrm{MN}$ ) were used in a sandwich enzyme-linked immunosorbent assay. Recombinant murine G-CSF (Peprotech, Rocky Hill, NJ) was used as a standard.

\section{Bio-Plex Analysis of Cytokines Including IL-17}

Vitreous humor samples and serum were evaluated for cytokine and chemokine levels with the Bio-Plex mouse cytokine 23-plex panel, used according to the manufacturer's instructions (Bio-Rad Laboratories, Hercules, CA). The assay was analyzed using a Bio-Plex 200 instrument and BioPlex Manager software version 5.0 (Bio-Rad Laboratories). IL-17 concentrations were measured using this kit.

\section{Ab Blockade Studies}

Rat anti-murine G-CSF mAb (clone 67604, as above) was used for G-CSF blockade in EAU, on the basis of our previous G-CSF neutralization experiments. ${ }^{31} \mathrm{mAb}(0.25$ $\mathrm{mg}$ ) (or a rat $\mathrm{IgG} 1$ control $\mathrm{mAb}$ ) was injected i.p. on day 8 and then every second day up to day 20 of EAU.

\section{G-CSF Administration}

For chemokine receptor expression and migration experiments, $2 \mu \mathrm{g}$ G-CSF per mouse (Neupogen; Amgen, Thousand Oaks, CA) was administered s.c. twice, 12 hours apart, and organs were harvested the next day. For the IFA and G-CSF experiment, $2 \mu \mathrm{g}$ G-CSF per mouse was administered s.c. for seven doses, 12 hours apart, over 3.5 days.

\section{MPO Assay}

MPO was quantified in enucleated, homogenized whole eyes with a mouse ELISA test kit (Hycult Biotech, Uden, the Netherlands), used according to the manufacturer's instructions.

\section{Histological Assessment of EAU}

Eyes were harvested from mice 21 days after immunization. Hematoxylin and eosin sections were scored by two separate observers (blinded to experimental group; X.C., P.G.M.) and averaged. Infiltrative and structural scores were combined to give the total histological score. The scoring system used was on the basis of the system described by Dick et al. ${ }^{36}$
Table 1 Flow Cytometry Reagents

\begin{tabular}{|c|c|c|}
\hline Antigen/fluorophore & Clone & Supplier \\
\hline \multicolumn{3}{|l|}{ Products } \\
\hline CD45.2-PercP-Cy5.5 & 104 & $\begin{array}{l}\text { BD Biosciences } \\
\quad(\text { San Jose, CA })\end{array}$ \\
\hline CD11b-FITC & M1/70 & BD Biosciences \\
\hline Gr-1-APC & $\mathrm{RB} 6.8 \mathrm{C} 5$ & BD Biosciences \\
\hline F480-FITC & $\mathrm{F} 4 / 80$ & $\begin{array}{l}\text { WEHI monoclonal } \\
\text { antibody facility }\end{array}$ \\
\hline CXCR2-PE & 242216 & R\&D Systems \\
\hline CD62L-PE-TX-RED & MEL-14 & Invitrogen \\
\hline CXCR4-APC & 2B11 & $\begin{array}{l}\text { eBioscience } \\
\quad \text { (San Diego, CA) }\end{array}$ \\
\hline$\gamma \delta-T C R-P E$ & B1 & BD Biosciences \\
\hline IL-17-APC & eBio17B7 & eBioscience \\
\hline GM-CSF-PE & MP1-22E9 & BD Biosciences \\
\hline IFN- $\gamma-$ FITC & XMG1.2 & eBioscience \\
\hline \multicolumn{3}{|l|}{ Reagent } \\
\hline AnnexinV-FITC & & BD Biosciences \\
\hline FluoroGold & & $\begin{array}{l}\text { Sigma-Aldrich } \\
\text { (St. Louis, M0) }\end{array}$ \\
\hline
\end{tabular}

APC, allophycocyanin; Cy5.5, cyanine5.5; FITC, fluorescein isothiocyanate; $\mathrm{PE}$, phycoerythrin; PercP, peridinin-chlorophyll proteins; TX-RED, Texas Red.

\section{Western Blot Analysis for Ocular IRBP}

Eye homogenates were clarified by centrifugation, and sample proteins $(20 \mu \mathrm{g})$ were run on $4 \%$ to $12 \%$ Bis-Tris NOVEX gels (Invitrogen, Carlsbad, CA), then transferred to a polyvinylidene difluoride membrane. IRBP was detected with rabbit-anti-IRBP (Santa Cruz Biotechnology, Santa Cruz, CA), followed by sheep-anti-rabbit Ig-horseradish peroxidase (Silenus, Melbourne, VIC, Australia). Immunoblots were developed with Amersham ECL (GE Healthcare, Little Chalfont, UK).

\section{Flow Cytometry}

Single-cell suspensions of PB, BM, and spleen were made by passage through a $70-\mu \mathrm{m}$ cell strainer. Single-cell suspensions were made by crushing enucleated eyes between two frosted slides. Antibodies used to stain leukocyte subsets are listed in Table 1.

\section{Intracellular Cytokine Staining}

Single-cell suspensions of the eye and blood were stimulated for 4 hours with $50 \mathrm{ng} / \mathrm{mL}$ phorbol myristate acetate (Sigma-Aldrich, St. Louis, MO) and $500 \mathrm{ng} / \mathrm{mL}$ ionomycin, $1 \mathrm{mg} / \mathrm{mL}$ brefeldin A, and $2 \mathrm{mg} / \mathrm{mL}$ monensin. Cells were stained with surface antibodies (Table 1). Cells were fixed and permeabilized with BD Cytofix/Cytoperm (BD Biosciences, San Jose, CA), used according to the manufacturer's instructions, and stained with anti-cytokine antibodies (Table 1), followed by resuspension in $1 \times \mathrm{BD}$ Perm/Wash buffer (BD Biosciences). Unstimulated cells were used as a control. 


\section{Antigen-Specific Proliferation Assay for EAU}

Whole splenocytes from WT and G-CSF-deficient mice, harvested 21 days after the induction of EAU, were stained with $5 \mu \mathrm{mol} / \mathrm{L}$ CellTrace Violet (Invitrogen). Cells $\left(2 \times 10^{5}\right.$ per well $)$ were cultured for 5 days in the presence or absence of $5 \mu \mathrm{g} / \mathrm{mL}$ IRBP 1-20. On day 5, cells were stained for CD3, CD4, and CD8 and propidium iodide to exclude dead cells. Stained cells were analyzed on a BD Fortessa flow cytometer.

\section{Retinal Disease Grading (in Vivo Imaging)}

The severity of retinal disease was assessed on the basis of examination of bright-field and fluorescent fundal images obtained from in vivo examination (Micron III; Phoenix Laboratories, Palmdale, CA). A modified version of a previously described grading scheme was used to score fundal images ${ }^{37}$ (Supplemental Table S1) by two observers (blinded to experimental group; X.C., P.G.M.), and the scores were averaged.

\section{In Vitro Stimulation of PB Neutrophils}

Splenocytes $\left(2 \times 10^{6}\right)$ were stimulated with $5 \mathrm{ng} / \mathrm{mL}$ human G-CSF (Neupogen) and murine granulocyte-macrophage colony-stimulating factor (GM-CSF; Peprotech), or incubated in media alone for 16 hours. Live neutrophils were defined as AnnexinV ${ }^{-}$FluoroGold ${ }^{-} \mathrm{Gr}^{-}{ }^{\text {hi }} \mathrm{CD} 11 \mathrm{~b}^{+} \mathrm{F} 4 / 80^{-}$ (BD Biosciences).

\section{Transwell Neutrophil Migration Assay}

A total of $1 \times 10^{6}$ cells $\left(1 \times 10^{7}\right.$ cells $\left./ \mathrm{mL}\right)$ were placed in the top chamber of a 3- $\mu \mathrm{m}$ pore, 24-well transwell plate (Corning, Tewksbury, MA). Media $(600 \mu \mathrm{L})$ containing 500 $\mathrm{ng} / \mathrm{mL}$ recombinant murine CXCL2/macrophage inflammatory protein (MIP)-2 (R\&D Systems), or media alone, were placed in the bottom chamber, and the plate was incubated for 30 minutes at $37^{\circ} \mathrm{C} / 5 \% \mathrm{CO}_{2}$. The ViaLight plus kit (Lonza, Basel, Switzerland) was used, according to the manufacturer's directions, to calculate migrating cells. The remaining cells were stained and analyzed by flow cytometry, with neutrophils defined as $\mathrm{Gr}-\mathrm{H}^{\mathrm{hi}} \mathrm{CD} 11 \mathrm{~b}^{+} \mathrm{F} 4 / 80^{-}$.

\section{Neutrophil Actin Polymerization Assay}

A previously reported actin polymerization assay was adapted. ${ }^{38}$ White blood cells were stained (neutrophils defined as Gr- $1^{\text {hi }} \mathrm{CD} 11 \mathrm{~b}^{+} \mathrm{F} 4 / 80^{-}$) and resuspended at $2 \times 10^{7} / \mathrm{mL}$, and $50 \mu \mathrm{L}$ was transferred to $5-\mathrm{mL}$ polystyrene tubes on ice. Samples were incubated at $37^{\circ} \mathrm{C}$ for 2 minutes, then murine MIP-2 (R\&D Systems) was added (final concentration of 500 $\mathrm{ng} / \mathrm{mL}$ ). Cells were incubated for $15,30,60$, or 120 seconds before BD Cytofix/Cytoperm was added. Samples were stained with phalloidin-fluorescein isothiocyanate and analyzed by flow cytometry.

\section{In Vivo Neutrophil Migration Assay}

B6/G-CSF-deficient and B6/G-CSF-R-deficient mice were injected s.c. with either $2 \mu \mathrm{g}$ hG-CSF or phosphatebuffered saline. Sixteen hours later, mice were injected i.p. with $500 \mathrm{ng}$ murine CXCL2/MIP-2 (Peprotech). After 4 hours, mice were bled and peritoneal lavages were performed with cold phosphate-buffered saline. Cell counts and flow cytometry were performed after lysis of red blood cells (RBCs). Cells were analyzed on an ADVIA blood analyzer (Siemens, Munich, Germany) and BD Fortessa. Neutrophils were defined as $\mathrm{CD} 45^{+} \mathrm{Gr}-1^{\text {hi }} \mathrm{CD} 11 \mathrm{~b}^{+} \mathrm{F} 4 / 80^{-}$.

\section{Statistical Analysis}

Prism software version 6 (GraphPad, La Jolla, CA) was used for statistical analysis. The $U$-test was used to compare sample groups, unless otherwise stated. Analysis of variance was used for measurements taken at multiple time points. Data shown are means \pm SEM.

\section{Results}

\section{G-CSF and Neutrophils Play Pivotal Roles during EAU}

EAU was induced in age- and sex-matched C57BL/6 mice, and PB leukocytes were analyzed by automated cell counting (Figure 1A). Neutrophils increased approximately 35-fold at day (d) 7, 20-fold at d11, and 10-fold at d15 and d21. In contrast, the increase in lymphocyte numbers was modest (2.5fold) on d7 and normalized by d15. G-CSF levels increased markedly by $\mathrm{d} 7$ and remained high throughout disease, correlating closely with increased circulating neutrophils (Figure 1B). In mice, MPO generation in tissues arises mainly from neutrophils, because monocytes/macrophages downregulate MPO production outside of the BM. ${ }^{39}$ MPO was, therefore, used as a surrogate marker for neutrophil infiltration in the eye. Ocular $\mathrm{MPO}^{40}$ increased throughout EAU and correlated with increased G-CSF levels within the eye (Figure 1C).

Anti-Gr-1 $\mathrm{mAb}^{41}$ was administered to WT mice to examine the effect of neutrophil depletion on EAU. As previously reported ${ }^{42}$ disease severity decreased $(P \leq 0.01)$ (Figure 1D). EAU was, therefore, compared in WT and G$\mathrm{CSF}-$ deficient mice. A significant reduction in the total histological score (comprising infiltrative and structural scores $^{36}$ ) was observed in G-CSF-deficient mice (Figure 1E). Although the infiltrative score (Figure 1F) did not differ between groups, the structural score was markedly reduced in G-CSF-deficient mice (Figure 1G). Figure $1 \mathrm{H}$ shows representative histological sections of WT and G-CSF-deficient mice. Consistent with these data, G-CSF-deficient mice maintained high IRBP levels (normalized to actin) compared with WT mice with EAU, indicating less retinal damage (Figure 1, I and $\mathrm{J}$ ). 

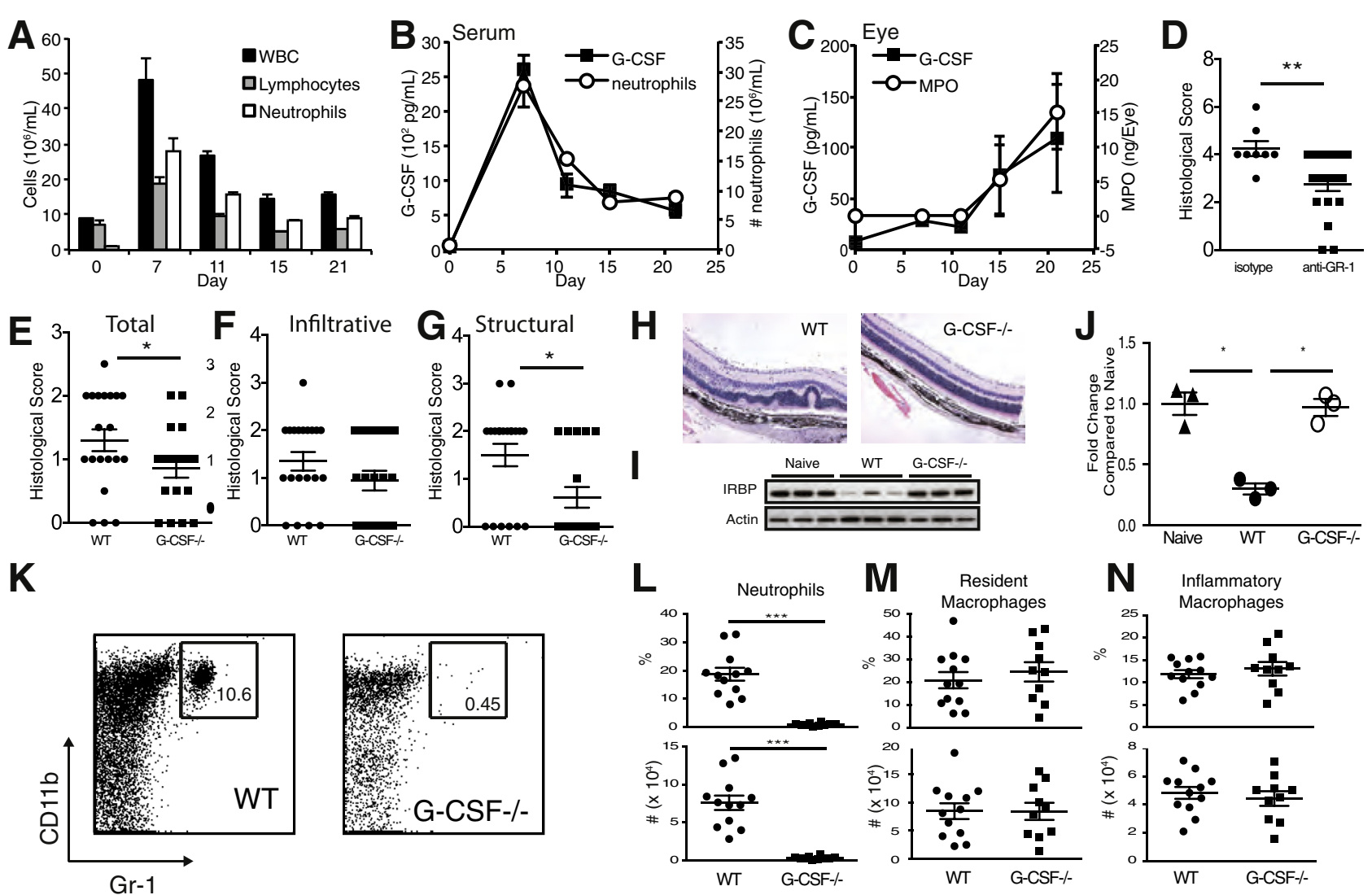

Figure 1 A critical role for granulocyte colony-stimulating factor (G-CSF) and neutrophils in experimental autoimmune uveoretinitis. A-C: Experimental autoimmune uveoretinitis (EAU) was induced in wild-type (WT) mice. Peripheral blood (PB) leukocytes were evaluated by ADVIA and G-CSF levels in serum and vitreous humor measured by BioPlex. A: PB white blood cell, lymphocyte, and neutrophil numbers throughout EAU. B: Increased serum G-CSF correlates with PB neutrophilia in EAU. C: Myeloperoxidase (MPO) activity (in total eye homogenate) and G-CSF levels in vitreous humor. D: EAU was induced in WT mice treated with either $0.5 \mathrm{mg} \mathrm{RB} 6 \mathrm{mAb}$ or isotype control [days (d) -1, 2, 5, and 7]. Disease severity was assessed histologically at d21. E-K: EAU was induced in WT or G-CSF-deficient mice. E-G: Eyes were examined histologically on d21 and scored for disease severity. Total histological score (E) assessed as the total of infiltrative histological score (F) and structural histological score (G). H: Representative examples of eye histology from WT or G-CSF-deficient mice with EAU. I: IRBP levels were determined in the eye by Western blot analysis in WT and G-CSF-deficient mice d21 after disease induction. J: Graphical representation of Western blot IRBP density. Eyes from WT and G-CSF-deficient mice were dissociated into single-cell suspensions and analyzed by flow cytometry $\mathrm{d} 21$ after induction of EAU. $\mathbf{K}$ and L: Infiltrating neutrophils ( $\left.\mathrm{CD} 45^{+} \mathrm{F} 4 / 80^{-} \mathrm{CD} 11 \mathrm{~b}^{\mathrm{hi}} \mathrm{Gr} 1^{\mathrm{hi}}\right)(\mathbf{K})$ and neutrophil proportions and numbers (L). $\mathbf{M}$ and $\mathbf{N}$ : Resident

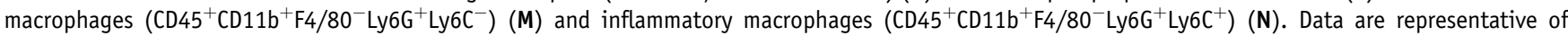
three independent experiments, $n=8$ to $17(\mathbf{B}) ; n=4$ to 8 (D); data are representative of two experiments, $n=9$ to 10 (E- $\mathbf{G}) ; n=3$ (I and $\mathbf{J}$, fold change relative to naïve WT mice); $n=7$ to 12 (M and $\mathbf{N}$ ). ${ }^{*} P<0.05,{ }^{*} P \leq 0.01$, and ${ }^{*} * P \leq 0.001$ by $U$-test.

Enucleated eyes were processed into single-cell suspensions and analyzed by flow cytometry. A substantial population of neutrophils was found in WT eyes on d21 of EAU, but was almost absent in G-CSF-deficient mice (Figure 1K), translating into a significant decrease in neutrophil numbers in the eyes of G-CSF-deficient mice (Figure 1L). In contrast, neither the proportion nor number of resident or inflammatory macrophages was altered in G-CSF-deficient mice (Figure 1, M and $\mathrm{N}$ ). These data show that, in the absence of G-CSF, neutrophil infiltration into the eye is markedly (and selectively) reduced and ocular damage is much less severe, without any apparent change in the monocyte-macrophage response.

To further explore the role of G-CSF in this model, EAU was induced in WT mice with pertussis and IFA alone or pertussis and IFA combined with seven doses of $2 \mu \mathrm{g}$ per mouse G-CSF over 3.5 days (days 0 to 3 ). Mice treated with IFA alone (with or without G-CSF) developed mild
(3 of 20) or no EAU (17 of 20) (data not shown), suggesting the early administration of G-CSF is not sufficient to replace the effect of complete Freund's adjuvant in the initiation of EAU.

\section{G-CSF Deficiency Does Not Affect T-Cell Proportion,} Number, or Antigen-Specific T-Cell Proliferation But Th Differentiation Is Altered in the Absence of G-CSF

IRBP peptide-induced EAU is considered a $\mathrm{CD} 4^{+} \mathrm{T}$ cell-mediated disease. ${ }^{43}$ There was no difference in the proportion (Figure 2, A and B) or number (Figure 2, $\mathrm{C}$ and $\mathrm{D}$ ) of total or $\mathrm{CD}^{+}{ }^{+}$ocular infiltrating $\mathrm{T}$ cells when comparing WT with G-CSF-deficient mice 21 days after induction of EAU. Global antigen-specific proliferation was assessed after EAU induction. There was no difference between IRBP-immunized WT and G-CSF-deficient mice in 

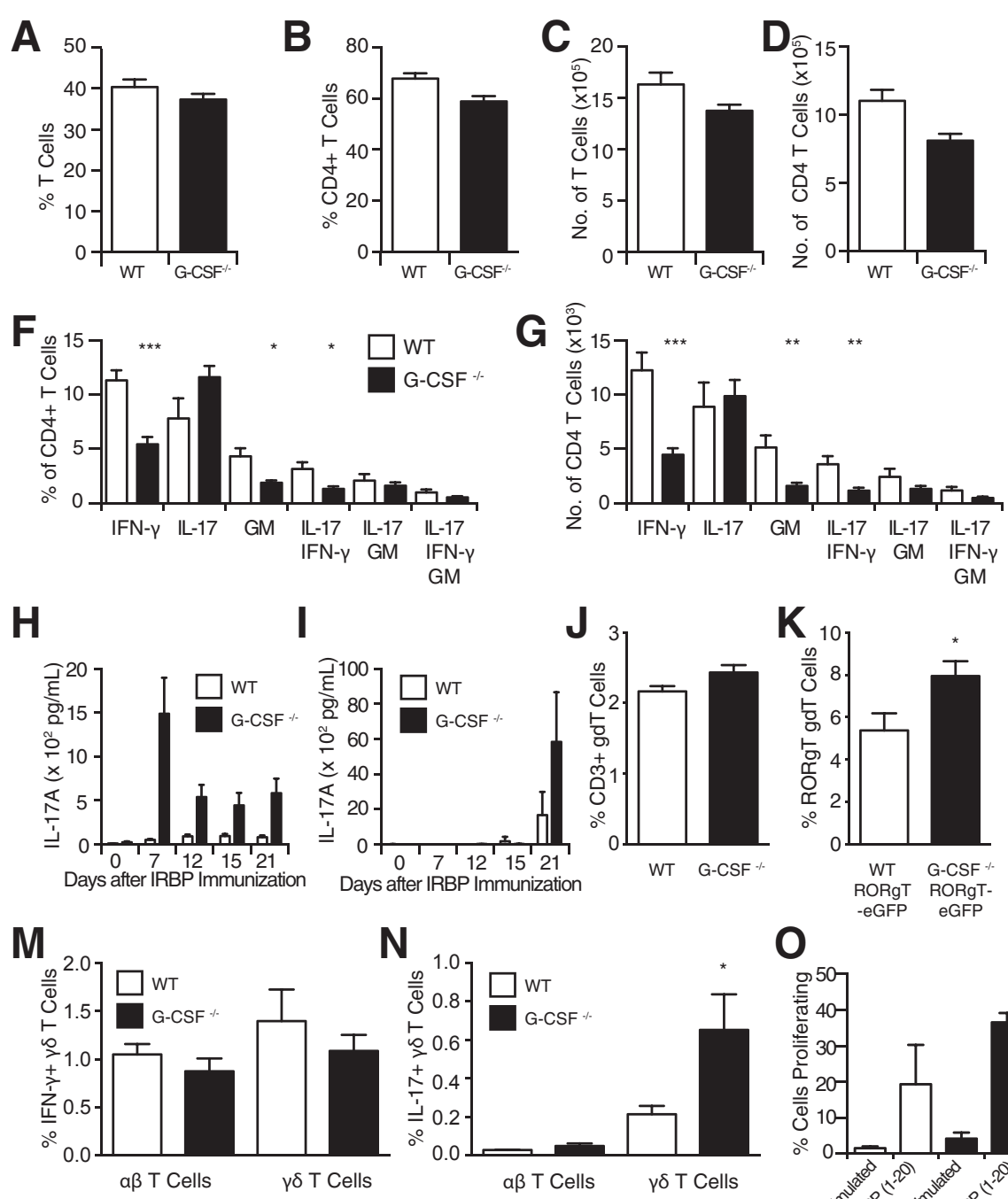

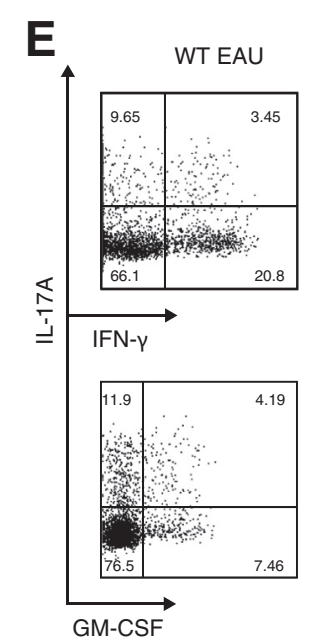

G-CSF $/-$ EAU

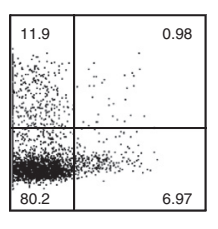

L

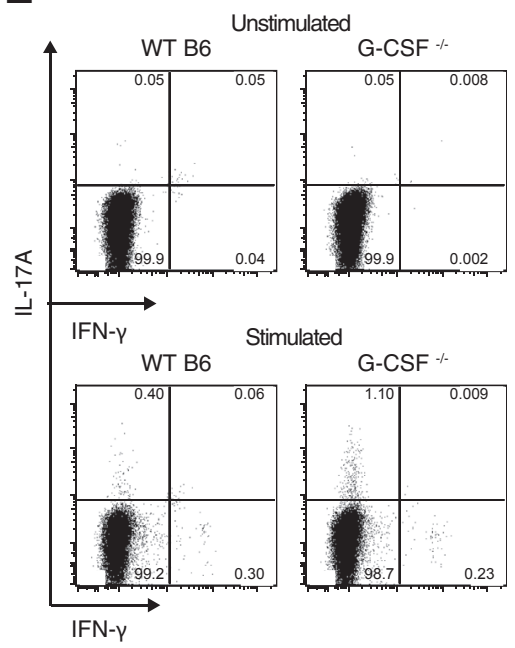

Figure 2 Global T-cell responses are maintained in granulocyte colony-stimulating factor (G-CSF)-deficient mice with experimental autoimmune uveoretinitis (EAU), but pathogenic Th17 cells are reduced in the eye. EAU was induced in wild-type (WT) or G-CSF-deficient mice. Proportion of CD45 ${ }^{+}$CD3 ${ }^{+}$ (A) and $\mathrm{CD}_{5} 5^{+} \mathrm{CD}_{3}{ }^{+} \mathrm{CD}^{+}{ }^{+}$(B) T cells. Number of $\mathrm{CD}_{4} 5^{+} \mathrm{CD} 3^{+} \mathrm{T}$ cells (C) and $\mathrm{CD} 45^{+} \mathrm{CD}^{+}{ }^{+} \mathrm{CD} 4^{+} \mathrm{T}$ cells (D). E: IL-17A, interferon (IFN)- $\gamma$, and GM-CSF production by $\mathrm{CD}^{+} \mathrm{CD}^{+} \mathrm{T}$ cells in the eye after 4 hours stimulation with $\mathrm{PMA}$ /ionomycin. Each dot plot is data concatenated from 7 to 10 mice [FlowJo software version 9.8.2 (FlowJo LLC, Ashland, OR)]. F: Proportions of $\mathrm{CD} 45^{+} \mathrm{CD}^{+} \mathrm{CD}^{+} \mathrm{IFN}-\gamma, \mathrm{IL}-17 \mathrm{~A}, \mathrm{GM}-\mathrm{CSF}, \mathrm{IL}-17 \mathrm{~A} / \mathrm{IFN}-\gamma, \mathrm{IL}-17 \mathrm{~A} / \mathrm{GM}-\mathrm{CSF}$, and IL-17A/IFN- $\gamma / \mathrm{GM}-\mathrm{CSF}$ producing cells in the eye. G: Number of $\mathrm{CD} 5^{+} \mathrm{CD}^{+} \mathrm{CD}^{+}$IFN- $\gamma$, IL-17A, GM-CSF, IL-17A/IFN- $\gamma$, IL-17A/GM-CSF, and IL-17A/IFN- $\gamma / \mathrm{GM}-\mathrm{CSF}$ producing cells in the eye. H: Serum IL-17 levels throughout EAU. I: Vitreous humor IL-17 levels throughout EAU. J: Proportion of $\mathrm{CD}^{+} \gamma \delta$-TCR ${ }^{+}$splenic T cells. K: Proportion of $\mathrm{ROR} \mathrm{T}^{+} \mathrm{CD}^{+} \gamma \delta-\mathrm{TCR}^{+}$splenic T cells. L: IL-17A and IFN- $\gamma$ production by $\mathrm{CD}^{+} \gamma \delta$-TCR ${ }^{+}$splenic T cells after 4 hours stimulation with PMA/ionomycin. M: Proportion of IFN- $\gamma$-producing $\mathrm{CD}^{+} \gamma \delta$-TCR ${ }^{+}$splenic T cells after 4 hours stimulation with PMA/ionomycin. N: Proportion of IL-17-producing $\mathrm{CD}^{+}{ }^{+} \gamma \delta$-TCR ${ }^{+}$ splenic T cells after 4 hours stimulation with PMA/ionomycin. 0: Proliferation of splenic T cells after 5 days without peptide, with IRBP peptide or with PMA. Data plotted as individual scores are representative of two experiments, $n=5$ to $10(\mathbf{I}) ; n=5$ to $6(\mathrm{~N})$; data representative of three separate experiments, $n=4(\mathbf{0}) .{ }^{*} P \leq 0.05,{ }^{*} P \leq 0.01$, and ${ }^{* *} P \leq 0.001, U$-test. GM-CSF, granulocyte-macrophage colony-stimulating factor; PMA, phorbol myristate acetate.

splenic T-cell proliferation after in vitro stimulation with IRBP peptide (Figure 2O). Recent studies have implicated the production of interferon (IFN)- $\gamma$ and/or GM-CSF by IL-17A-producing $\mathrm{CD}^{+} \mathrm{T}$ cells in the pathogenesis of experimental allergic encephalomyelitis (EAE). ${ }^{44}$ Cytokine production by $\mathrm{CD} 4^{+} \mathrm{T}$ cells 21 days after EAU induction was, therefore, analyzed (Figure 2E). The proportion and number of IFN- $\gamma$ alone, GM-CSF alone, and IL-17A/IFN- $\gamma$-producing ocular $\mathrm{CD}^{+} \mathrm{T}$ cells was reduced in ${\mathrm{G}-\mathrm{CSF}^{-/-}}^{\text {mice }}$ (Figure 2, F and G). IL-17A levels were also analyzed in the serum and vitreous humor throughout the course of EAU.
There was no difference between WT and G-CSF-deficient mice in baseline levels, but from d7, serum IL-17A increased markedly in G-CSF-deficient mice compared with WT mice, and this difference was maintained throughout the course of EAU (Figure 2H). By d21, IL-17A was detectable in vitreous humor, and the levels appeared higher in G-CSF-deficient mice (Figure 2I).

Increased serum IL-17A seemed paradoxical given the decreased EAU we observed and, thus, was further investigated. $\gamma \delta \mathrm{T}$ cells are the predominant source of $\mathrm{IL}-17$ in collagen-induced arthritis ${ }^{45}$ and play an important role in 

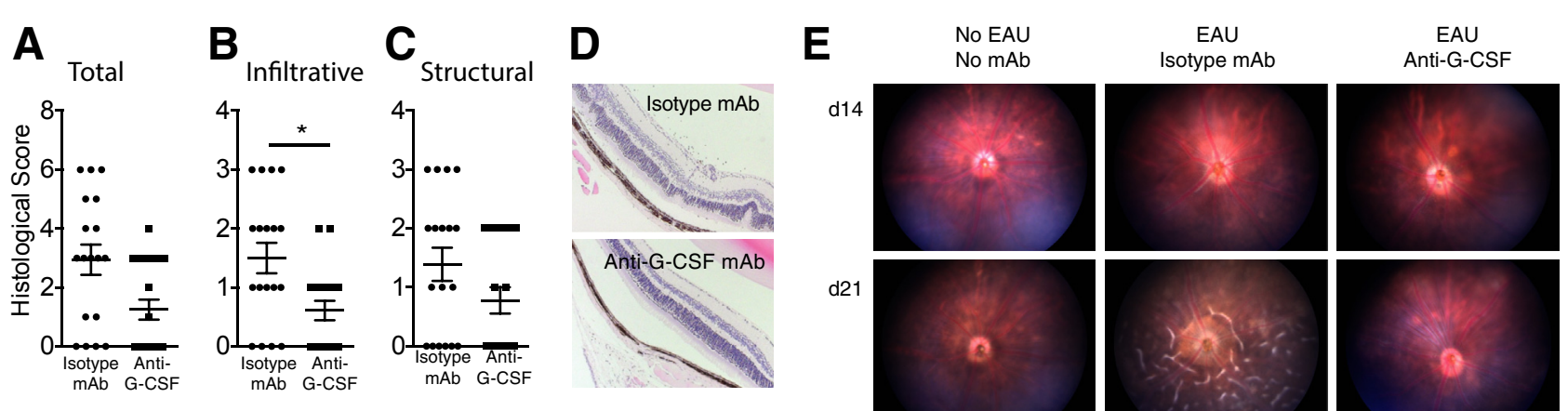

d21
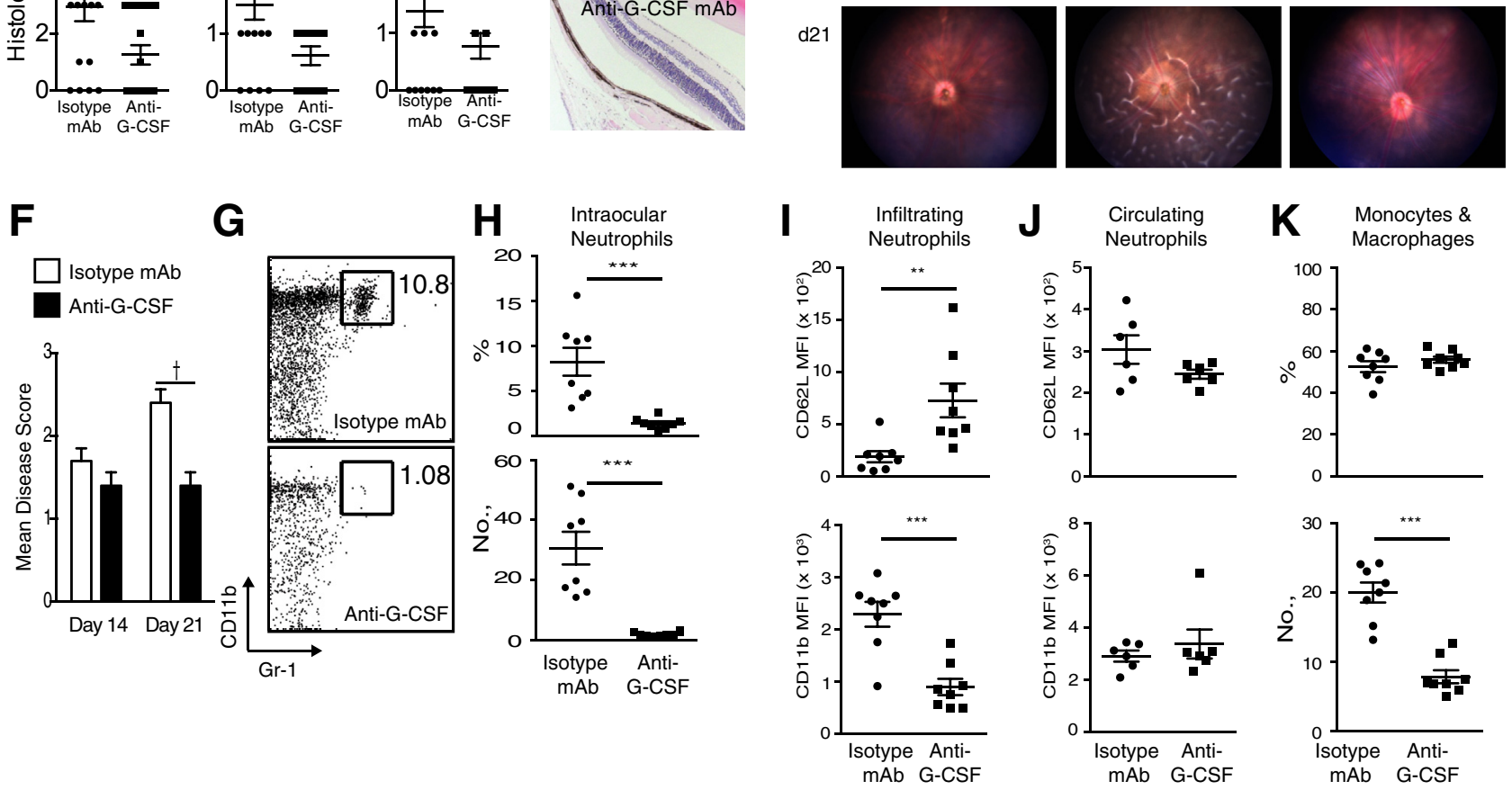

Figure 3 Granulocyte colony-stimulating factor (G-CSF) antagonism reduces the severity and incidence of experimental autoimmune uveoretinitis (EAU). Anti-G-CSF or isotype control monoclonal antibody (mAb; $250 \mu \mathrm{g}$ ) was administered to wild-type (WT) mice every second day between days 8 to 20 after EAU induction. A-C: Eyes were examined histologically on day (d) 21 and scored for disease severity. A: Total histological score. B: Infiltrative histological score. C: Structural histological score. D: Representative histological sections of eyes from mice treated with either isotype-matched control mAb or anti-G-CSF mAb. E: The fundus of anesthetized mice under bright field microscopy. F: Severity of EAU, as assessed by bright field microscopy of anesthetized mice on d14 and d21, scored by an observer blinded to experimental group (X.C., P.G.M.). G-K: Whole eyes were analyzed by flow cytometry on d21 of EAU. G: Dot plot of intraocular neutrophils (defined as $\mathrm{CD} 45^{+} \mathrm{F} 4 / 80^{-} \mathrm{CD} 11 \mathrm{~b}^{\mathrm{hi}} \mathrm{Gr} \mathrm{1}^{\mathrm{hi}}$ ). H: Neutrophil proportions and numbers. I and J: Activation markers $\mathrm{CD} 62 \mathrm{~L}$ and $\mathrm{CD} 11 \mathrm{~b}$ were analyzed on infiltrating (I) and circulating ( $\mathbf{J})$ neutrophils. K: Macrophage and monocyte (CD45 ${ }^{+} \mathrm{GR}-1^{-} \mathrm{CD} 11 \mathrm{~b}^{+}$and/or F4/80 ${ }^{+}$) proportions and numbers. Data are representative of two experiments. $n=9$ to $10(\mathbf{A}-\mathbf{C}) ; n=5$ (E and $\mathbf{F}) ; n=8(\mathbf{H}-\mathbf{K}) .{ }^{*} P \leq 0.05,{ }^{*} P \leq 0.01$, and ${ }^{* * *} P \leq 0.001 U$-test; ${ }^{\dagger} P \leq 0.05$ analysis of variance test.

EAU. ${ }^{46} \mathrm{IL}-17$ production by $\gamma \delta \mathrm{T}$ cells has been reported to increase serum G-CSF and circulating neutrophils in a metastatic tumor model. ${ }^{47} \mathrm{We}$, therefore, evaluated whether $\gamma \delta \mathrm{T}$ cell proportions or IL-17A production by $\gamma \delta \mathrm{T}$ cells was altered in G-CSF-deficient mice. Splenic $\gamma \delta$ T-cell proportions were unchanged in naïve G-CSF-deficient mice when compared with WT B6 mice (Figure 2J). However, there was an increase in splenic ROR $\gamma \mathrm{T}^{+} \gamma \delta \mathrm{T}$ cells in naïve G-CSF-deficient ROR $\gamma$ T-eGFP mice compared with WT ROR $\gamma$ T-eGFP mice (Figure 2K). Splenocytes from WT B6 mice and G$\mathrm{CSF}$-deficient mice were stimulated with phorbol myristate acetate and ionomycin, and representative plots of $\gamma \delta \mathrm{T}$-cell cytokine production are depicted in Figure $2 \mathrm{~L}$. There was no difference in IFN- $\gamma$ production by $\alpha \beta$ or $\gamma \delta$ T cells (Figure $2 \mathrm{M}$ ) or in IL-17 production by $\alpha \beta$ T cells (Figure $2 \mathrm{~N}$ ), but there was a marked increase in IL-17 production by splenic $\gamma \delta \mathrm{T}$ cells from G-CSF-deficient mice (Figure 2N). These data demonstrate that conventional $\mathrm{CD} 4^{+} \mathrm{T}$-cell proportions and antigenspecific proliferative responses are preserved in the absence of G-CSF. IL-17A production is enhanced in G-CSF deficiency, but appears to arise from an expanded population of $\mathrm{ROR} \gamma \mathrm{T}^{+} \gamma \delta \mathrm{T}$ cells. In contrast, the differentiation of pathogenic Th17 cells infiltrating the eye in EAU is reduced with G-CSF deficiency.

\section{G-CSF Antagonism after the Initiation of EAU Reduces Disease Severity and Local Neutrophil Trafficking and Activation}

In preliminary studies, we found that histological changes in the eye commence approximately 8 days after immunization with IRBP. To further explore the contribution of G-CSF, and to model a more clinically relevant disease and therapeutic scenario, WT mice were treated with anti-G-CSF from d8 to d20 after initiation of EAU. The Micron III retinal imaging system was used for in vivo imaging of eyes on $\mathrm{d} 14$ and $\mathrm{d} 21$, and histological evaluation and flow cytometric analysis were performed on $\mathrm{d} 21$. Treatment of 

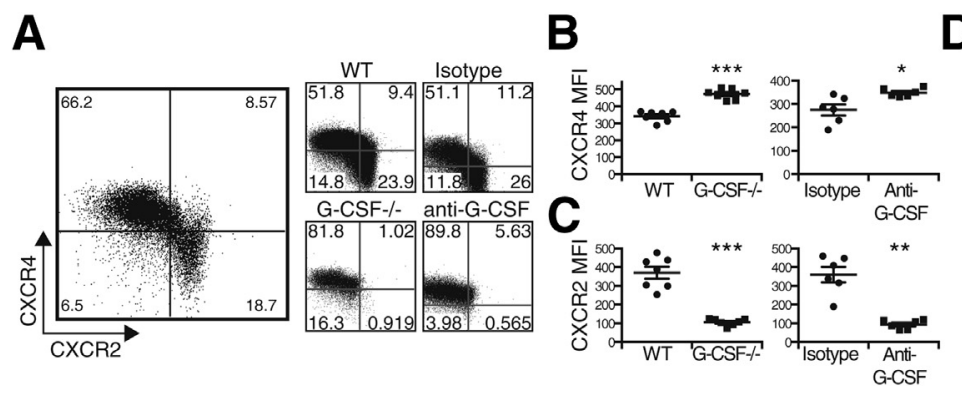

D

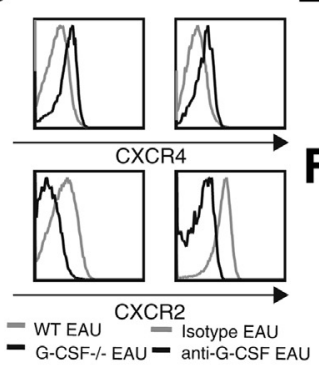

E

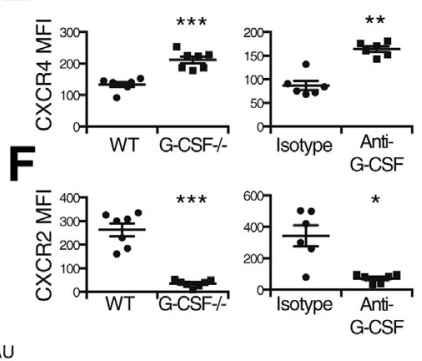

G

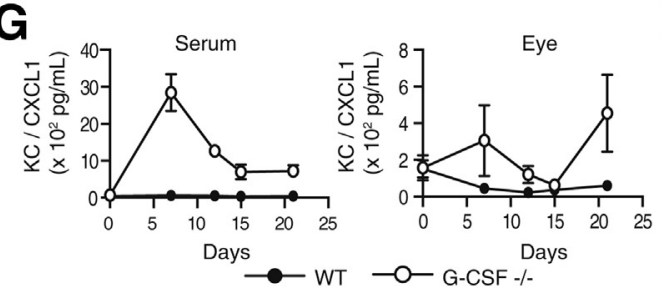

H

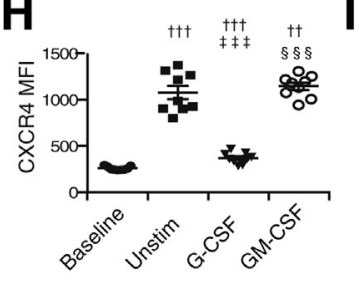

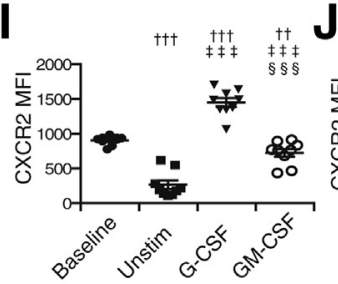

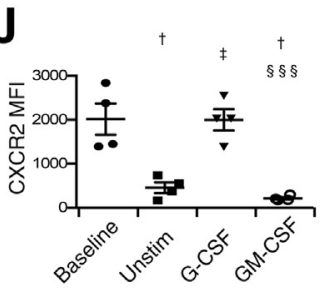

Figure 4 Granulocyte colony-stimulating factor (G-CSF) signaling regulates C-X-C chemokine receptors (CXCRs) 2 and 4 expression on bone marrow and peripheral blood neutrophils in mice with experimental autoimmune uveoretinitis (EAU) and in human neutrophils. A-F: EAU was induced in WT and G-CSF-deficient mice or isotype mAb-treated and anti-G-CSF mAb-treated WT mice (250 $\mu$ g every second day, days 8 to 20$)$. Cells in bone marrow (BM; A-C) and peripheral blood (PB; D-F) were analyzed by flow cytometry on day 21 . Neutrophils were defined as $\mathrm{CD} 11 \mathrm{~b}^{+} \mathrm{F} 4 / 80^{-} \mathrm{Gr}-1^{+}$. A: Representative dot plots of CXCR4 and CXCR2 expression on BM neutrophils. B: CXCR4 expression on BM neutrophils. C: CXCR2 expression on BM neutrophils. D: Representative histograms of CXCR4 and CXCR2 expression on PB neutrophils. E: CXCR4 expression on PB neutrophils. F: CXCR2 expression on PB neutrophils. G: CXCL1/KC concentration in serum and eye fluid of WT and G-CSF-deficient mice throughout EAU. H: Spleen cells stimulated with G-CSF, GM-CSF, or media alone and CXCR4 expression was analyzed on CD11 b ${ }^{+} 4 / 80^{-} \mathrm{Gr}^{+}$neutrophils at baseline and 20 hours. I: Spleen cells stimulated with G-CSF, GM-CSF, or media alone and CXCR2 expression was analyzed on $\mathrm{CD} 11^{\mathrm{b}+} \mathrm{F} 4 / 80^{-} \mathrm{Gr}-1^{+}$neutrophils at baseline and 20 hours. J: Human WBCs stimulated with G-CSF, GM-CSF, or media alone. CXCR2 expression on $\mathrm{CD}_{16}{ }^{+} \mathrm{CD}_{6} 6 \mathrm{~b}^{+}$FluoroGold ${ }^{-}$AnnexinV- neutrophils at baseline and 20 hours. Data plotted as individual scores with means \pm SEM and representative of two experiments $(\mathbf{A}-\mathbf{J}) . n=6$ to $7(\mathbf{A}-\mathbf{F}) ; n=4$ to $7(\mathbf{G}) ; n=8(\mathbf{H}$ and $\mathbf{I}) ; n=4$ (J). ${ }^{*} P<0.05,{ }^{* *} P<0.01$, and ${ }^{* * *} P<0.001$; ${ }^{\dagger} P<0.05,{ }^{\dagger \dagger} P<0.01$, and ${ }^{\dagger \dagger \dagger} P<0.001$ compared to baseline; ${ }^{\ddagger} P<0.05,{ }^{\ddagger \ddagger \ddagger} P<0.001$ compared to unstimulated; ${ }^{\S \S \S} P<0.001$ compared to G-CSF, U-test.

WT mice with anti-G-CSF significantly reduced the severity of EAU (Figure 3A). The infiltrative histological score was significantly reduced (Figure $3 \mathrm{~B}$ ), and the structural score was reduced (but did not reach significance) (Figure 3C). Figure 3D shows representative histological sections of WT and anti-G-CSF-treated mice. In vivo imaging on d14 of LysM-Cre-eGFP mice (used later to assess neutrophil infiltrate), treated with either anti-G-CSF or an isotype control, showed patchy perivasculitis, some focal infiltrates, and mild vitreous haze in both WT and anti-G-CSF-treated mice (Figure 3, A-C and H-K). By $\mathrm{d} 21$, abnormalities had progressed in control mice to widespread retinal edema, extensive retinal folds, focal granulomas, and perivasculitis, but were much less evident in anti-G-CSF-treated mice (Figure 3E). Although both isotype-treated and anti-G-CSF-treated WT mice had equivalent disease features at $\mathrm{d} 14$, progression to severe $\mathrm{EAU}$ by d21 was reduced with anti-G-CSF treatment (Figure 3F).

Remarkably, neutrophil infiltration of the eye was almost completely abrogated by treatment of WT mice with anti-G-CSF from d8 to d20 of EAU (Figure 3, G and H). This effect could not be explained by the decrease in proportion of neutrophils in the PB (WT versus anti-G-CSF EAU, $46.6 \% \pm 5.1 \%$ versus $12.1 \% \pm 2.0 \%$ ). Infiltrating neutrophils in the isotype-mAb-treated mice with EAU were activated $\left(\mathrm{CD} 62 \mathrm{~L}^{\mathrm{lo}} \mathrm{CD} 11 \mathrm{~b}\right.$ hi $)$ (Figure 3I). In contrast, infiltrating neutrophils from the anti-G-CSF-treated mice had a less activated phenotype $\left(\mathrm{CD} 62 \mathrm{~L}^{\mathrm{hi}} \mathrm{CD} 11 \mathrm{~b}^{\mathrm{lo} / \mathrm{int}}\right)$, suggesting G-CSF antagonism regulates infiltrating neutrophil activation. However, these differences were not observed in blood neutrophils (Figure 3J), implying local regulation. Again, the proportions of monocytes/macrophages in the eyes of anti-G-CSF-treated mice were similar to those of WT mice with EAU (Figure 3K), although the absolute number of these cells was decreased because of a decrease in the total number of $\mathrm{CD} 45^{+}$cells infiltrating the eye.

\section{Neutrophil CXCR4 and CXCR2 Expression Is Altered by G-CSF Signaling}

CXCR2 and CXCR4 chemokine receptors mediate neutrophil release from the BM and entry into inflamed peripheral tissues. ${ }^{13}$ Given the specific reduction we observed in neutrophil trafficking into the eye with G-CSF deficiency or blockade, we analyzed neutrophil expression of CXCR2 and CXCR4 in the PB of mice with EAU and compared this with BM (Figure 4, A-F). A population of $\mathrm{Gr}-1^{+} \mathrm{CD} 11 \mathrm{~b}^{+}$neutrophils from G-CSF-deficient and anti-G-CSF-treated WT mice expressed CXCR4 in the BM, as did those from WT mice. Neutrophils from G-CSF-deficient and anti-G$\mathrm{CSF}-$ treated BM failed to up-regulate CXCR2 (Figure 4A). CXCR4 expression was increased (Figure 4B) and CXCR2 decreased (Figure 4C) on BM neutrophils in both G-CSF-deficient and anti-G-CSF-treated mice. Similar 

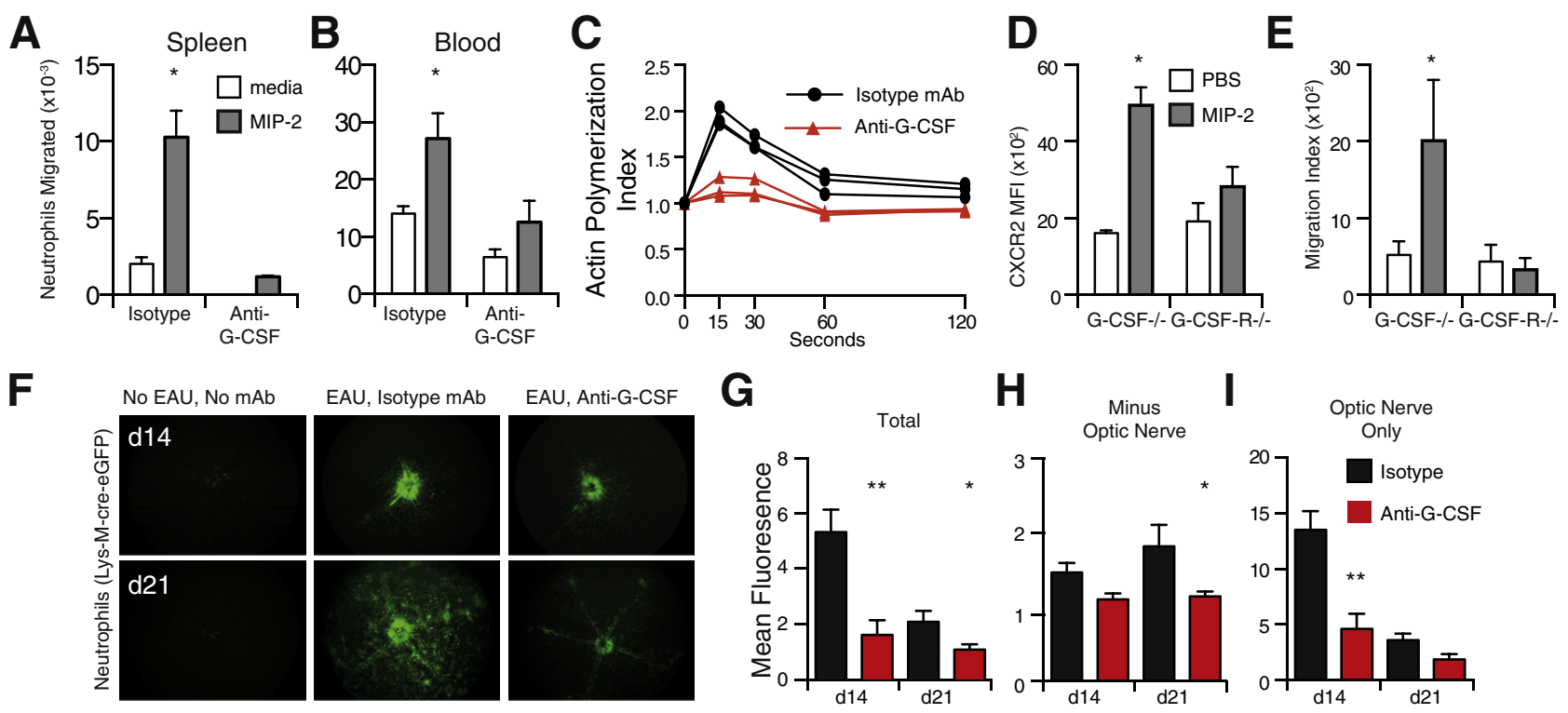

Figure 5 Granulocyte colony-stimulating factor (G-CSF) mediated changes in C-X-C chemokine receptor 2 (CXCR2) expression have functional consequences for neutrophil migration. A and B: Transwell migration assays performed on neutrophils from isotype- or anti-G-CSF-treated WT mice d21 of experimental autoimmune uveoretinitis. CXCL2/macrophage inflammatory protein 2 (MIP-2) was used as a chemotactic stimulus. Neutrophils (Gr- $\left.1^{\text {hi }} C D 11 b^{\text {hi }} F 4 / 80^{\text {neg }}\right)$ from spleen (A) and peripheral blood (PB; B). C: Actin polymerization in response to CXCL2/MIP-2 assessed by flow cytometry in mice treated with anti-G-CSF or control. D and E: G-CSF-deficient and G-CSF-R-deficient mice were injected with G-CSF or phosphate-buffered saline (PBS). Sixteen hours later, mice were injected i.p. with CXCL2/MIP-2 to induce neutrophil migration into the peritoneum. Expression of CXCR2 on PB neutrophils (D) and migrating neutrophils (E), expressed as a migration index. F: Intraocular eGFP expressing cells at day (d)14 and d21 following treatment with anti-G-CSF or control. Quantification of LysMcre-eGFP (neutrophils are eGFPhi) in eyes $\mathrm{d} 14$ and d21 after EAU induction. $\mathbf{G}$ and $\mathbf{H}$ : Total retinal fluorescence $(\mathbf{G})$ and fluorescence in the optic nerve region (H). I: Total fluorescence minus optic nerve region. ${ }^{*} P \leq 0.05,{ }^{*} P \leq 0.01 . n=3$, each replicate contains three to four pooled organs/PB (A and $\left.\mathbf{B}\right) ; n=5(\mathbf{F})$.

trends were observed in PB neutrophils (Figure 4, D-F), in steady-state G-CSF-deficient mice, and in WT B6 mice treated with anti-G-CSF mAb (Supplemental Figure S1). Serum levels of CXCL1/KC/GRO $\alpha$, a ligand for CXCR2, were increased in G-CSF-deficient mice as early as 7 days and remained elevated throughout EAU (Figure 4G). In the vitreous humor, CXCL1, a ligand for CXCR2 that is produced by ciliary epithelial cells, ${ }^{48}$ was also increased on $\mathrm{d} 7$ and d21 in G-CSF-deficient mice (Figure 4G).

\section{G-CSF Regulates Expression of CXCR4 and CXCR2 on Peripheral Neutrophils, Independent of Cell Survival}

G-CSF administration increased CXCR2 and decreased CXCR4 expression on PB neutrophils (Supplemental Figure S1). To determine whether G-CSF can directly mediate these responses, WT spleen cells were stimulated with G-CSF or GM-CSF for 16 hours. GM-CSF was included to control for an effect on neutrophil survival (Figure 4, H and I). To eliminate dead, dying, and apoptotic cells, cells were stained with AnnexinV and FluoroGold, and only AnnexinV ${ }^{-}$FluoroGold ${ }^{-} \mathrm{GR}-1^{\text {hi }} \mathrm{CD} 11 \mathrm{~b}^{+} \mathrm{F} 480^{-}$ neutrophils were analyzed. As expected, baseline CXCR4 expression was low (Figure $4 \mathrm{H}$ ). After overnight incubation in the absence of G-CSF or GM-CSF, CXCR4 was up-regulated (Figure $4 \mathrm{H}$ ). Addition of G-CSF, but not GM-CSF, prevented this up-regulation (Figure $4 \mathrm{H}$ ). In contrast, mature peripheral neutrophils express high levels of CXCR2, which is typically down-regulated in vitro
(Figure 4I). Although GM-CSF maintained CXCR2 expression, G-CSF significantly increased its expression (Figure 4I). The effect of G-CSF on CXCR2 expression was also confirmed in human white blood cells (Figure 4J). G-CSF maintained high expression of CXCR2, whereas CXCR2 was down-regulated on human neutrophils cultured alone, or with GM-CSF (Figure 4J). These data demonstrate that G-CSF can regulate CXCR2 and CXCR4 expression on peripheral neutrophils that have exited the BM compartment.

\section{G-CSF-Mediated CXCR2 Expression Is Required for Neutrophil Migration, in Vitro and in Vivo}

To examine the functional significance of G-CSF-induced changes in chemokine receptor expression, transwell assays were performed with splenocytes or PB neutrophils from mice with EAU that had been treated with anti-G-CSF or isotype mAbs. Cells were placed in the top chamber, and CXCL2/MIP-2 in the bottom. Cells migrating to the bottom chamber were analyzed by flow cytometry and ViaLight assay, and the number of migrating neutrophils was calculated. Significantly fewer splenic (Figure 5A) and PB (Figure 5B) neutrophils from anti-G-CSF-treated mice migrated in response to CXCL2, compared with isotype control mAb treatment. Actin polymerization is essential for neutrophil migration. ${ }^{49} \mathrm{~PB}$ cells were stimulated with CXCL2/MIP-2 and stained with phalloidin-fluorescein isothiocyanate, which binds filamentous or F-actin. GR$1^{+} \mathrm{CD} 11 \mathrm{~b}^{+}$neutrophils from WT mice with EAU that had 
been treated with isotype control mAb underwent normal actin polymerization and depolymerization (Figure 5C). In contrast, neutrophils from WT mice with EAU that had been treated with anti-G-CSF mAb failed to undergo actin polymerization in response to CXCL2/MIP-2 stimulation.

We assessed whether these in vitro chemotactic differences translated into a change in neutrophil migration in vivo. PB neutrophils from G-CSF- and G-CSF-R-deficient mice express lower levels of CXCR2. We, therefore, injected G-CSF- and G-CSF-R-deficient mice with G-CSF (or phosphate-buffered saline) s.c., 12 hours before injecting the chemoattractant CXCL2/MIP-2 into a different anatomical compartment, namely the peritoneal cavity. Four hours after injection of CXCL2, peritoneal lavages and $\mathrm{PB}$ were analyzed. PB neutrophil CXCR2 expression was increased after G-CSF administration to G-CSF-deficient, but not G-CSF-R-deficient, mice (Figure 5D). The number of infiltrating neutrophils in the peritoneal cavity was calculated as a percentage of PB neutrophil number to generate a migration index. Consistent with our data from the transwell assays, in vivo neutrophil migration in response to CXCL2 was increased after G-CSF administration in G-CSF-deficient mice, but not in G-CSF-R-deficient mice (Figure 5E).

To examine neutrophil trafficking in vivo during disease, ocular eGFP expression was analyzed in LysM-Cre-eGFP reporter mice with EAU. At d14, there was early perivasculitis and abnormal fluorescence of the optic nerve, which was less evident in anti-G-CSF-treated mice compared with the isotype-matched control. In contrast, on d21 of EAU, there were markedly more eGFP ${ }^{\text {hi }}$ neutrophils in the eyes of the isotype-treated EAU mice (Figure 5, F and $\mathrm{G}$ ). At d14, total fluorescence (a measure of neutrophil infiltration) was decreased in mice treated with anti-G-CSF. Separating fluorescence in the region of the optic nerve from the rest of the eye revealed a decrease in eGFP fluorescence around the optic nerve at $\mathrm{d} 14$ and in the rest of the retina at d21 in anti-G-CSF-treated mice (Figure 5, H and I). These data demonstrate that G-CSF antagonism decreases neutrophil migration in response to the CXCR2 ligand, CXCL2, both in vitro and in vivo, and reduces retinal damage in EAU.

\section{Discussion}

Neutrophils are traditionally considered as ancillary cells during sterile inflammation, contributing to non-specific host tissue damage. In this study, we have demonstrated that neutrophils and G-CSF play critical effector roles in EAU, a classic experimental model of organ-restricted, T-cell-mediated autoimmunity. Serum G-CSF increased early in EAU, and tracked closely with elevation of the PB neutrophil count. Subsequently, ocular G-CSF levels increased in the inflamed eye, associated with increased ocular MPO. These kinetics suggest a bimodal effect and are consistent with G-CSF acting early to increase BM granulopoiesis, and later acting locally at the inflammatory site. Histological analysis and in vivo imaging demonstrated that the severity of EAU was markedly decreased in G-CSF-deficient mice and after G-CSF antagonism, whereas flow cytometric analysis showed that in the absence of G-CSF, the ocular neutrophil population in EAU was profoundly reduced. Although the G-CSF receptor is expressed most abundantly on neutrophils, it is also found on monocytes and G-CSF can induce cytokine production in human and mouse monocytes. $^{50,51}$ Monocytes/macrophages are known to play an important role in $\mathrm{EAU},{ }^{52}$ and it is therefore possible that the absence or blockade of G-CSF in the setting of EAU may also reduce monocyte activation. ${ }^{11}$ However, we found no change in infiltrating monocyte subsets in the eye associated with G-CSF blockade or deficiency.

We found that CXCR2 neutrophil expression was markedly decreased in G-CSF-deficient, G-CSF-R-deficient, and anti-G-CSF-treated mice, whereas expression was increased in mice administered G-CSF. Conversely, CXCR4 expression was up-regulated in G-CSF-deficient, G-CSF-R-deficient, and anti-G-CSF-treated mice and was decreased in mice administered G-CSF. Reduced CXCR2 expression on peripheral neutrophils translated into functional defects in actin polymerization and reduced in vitro and in vivo neutrophil migration in response to a CXCR2 ligand. These effects were not simply because of differential neutrophil survival, because although both GM-CSF and G-CSF increased the survival of neutrophils in vitro, only G-CSF down-regulated CXCR4 and up-regulated CXCR2 expression on mature neutrophils. In a model of endotoxin-induced uveoretinitis, ocular leukocytic infiltrate was decreased in CXCR2-deficient mice. $^{53}$ Increased G-CSF-R mRNA, CXCR2, and CXCL1 have been found in the eye in EAU. ${ }^{54}$ G-CSF is produced by endothelial cells in the eye, and these cells also express the G-CSF-R. ${ }^{55}$ We suggest that tissuederived G-CSF, most likely derived from ocular endothelial cells, may play several key roles during inflammatory eye disease. These include production of chemokines by endothelial cells, ${ }^{13,56}$ increasing the expression of adhesion receptors on these cells, fine-tuning the expression of CXCR2 and CXCR4 chemokine receptors on neutrophils to promote neutrophil trafficking, and also extending the survival of neutrophils that have entered inflamed tissues. ${ }^{19,57}$

Previous studies identified important roles for Th1 cells and IL-12 in EAU and EAE ${ }^{58-60}$ However, it now appears that Th17 cells are the dominant pathogenic T-cell subset in both diseases, with IL-23, rather than IL-12, playing a nonredundant role. ${ }^{60}$ Only those T cells exposed to IL-23 were able to cause EAE, ${ }^{61}$ and IL-23-induced production of GM-CSF by Th17 cells was essential for the encephalitogenicity of T cells. ${ }^{62-64} \mathrm{~A}$ more recent study in EAE demonstrated that the $\mathrm{IL}-17^{+} \mathrm{IFN}-\gamma^{+}$ subset of $\mathrm{CD}^{+} \mathrm{T}$ cells contained the highest proportion of antigen-specific cells (as measured by tetramer staining), ${ }^{64}$ and these cells were also the highest producers of GM-CSF. ${ }^{64}$ Herein, we show that, although antigen-specific T-cell proliferative responses are intact in IRBP peptide-immunized 
G-CSF-deficient mice, T-cell differentiation is perturbed. We found a marked increase in IL-17A levels in G-CSF-deficient mice with EAU. Further analysis showed this most likely arises from a population of ROR $\gamma \mathrm{T}^{+} \gamma \delta \mathrm{T}$ cells that appears to produce increased IL-17 with G-CSF deficiency. This interesting finding requires more investigation, but would not explain reduced EAU and, in fact, argues that a systemic increase in IL-17 is by itself insufficient to provoke neutrophil-driven inflammatory disease. In contrast, there was a decrease in proportion and number of $\mathrm{CD}^{+}$cells in the eye producing the critical combination of IL-17A and IFN- $\gamma$ or GM-CSF alone, corresponding to the T cells implicated in driving EAE. ${ }^{64}$ Our findings are in keeping with a recent report in EAE, showing G-CSF-R-deficient mice have less marked disease after transfer of myelin-reactive Th17 cells, ${ }^{65}$ and suggest a two-way interaction between neutrophils and Th17 cells.

Potential interactions between Th17 cells and neutrophils are intriguing. Activated neutrophils can produce factors, such as IL-1, that influence Th17 polarization via effects on DC and the production of IL-23. ${ }^{66}$ Neutrophils can produce IL-17, as well as cytokines and chemokines that attract Th17 cells ${ }^{67}$ and, in turn, (human) Th17 cells can produce the neutrophil chemoattractant, IL-8. ${ }^{68}$ In EAU, transgenic IRBP-specific $\mathrm{T}$ cells are able to penetrate the blood-ocular barrier in two waves, with the second occurring approximately 4 days after transfer. ${ }^{69}$ At this time point, if ocular antigen-specific $T$ cells encounter cognate antigen in the context of major histocompatibility complex class II on resident antigen presenting cells, ${ }^{70-72}$ an inflammatory response is initiated. The ensuing cytokine and chemokine production activates the vascular endothelium, promoting the influx of inflammatory cells. In EAE, neutrophils are required for breakdown of the blood-brain barrier. ${ }^{73} \mathrm{We}$ found that ocular infiltration of neutrophils associates with structural damage to the retina, potentially releasing IRBP for uptake and presentation by local antigen presenting cells. Interestingly, ovalbumin-presenting neutrophils can directly stimulate OVA-specific, MHC class II-restricted $\mathrm{T}$ cell receptor (OT-II) T cells, and ovalbumin-pulsed neutrophils stimulated both IFN- $\gamma$ and IL-17 production by OT-II T cells. ${ }^{60}$ In a mouse model of allergic contact dermatitis, T-cell priming and IFN- $\gamma$ production were markedly reduced in neutrophil-depleted mice. ${ }^{74}$ In a recent article, Warnatsch et $\mathrm{al}^{51}$ demonstrated neutrophil extracellular trap-mediated macrophage priming and the subsequent polarization/activation of Th17 cells. Furthermore, IL-17A, CXCL1, CXCL2, and chemokine ligand 2 were decreased in the atherosclerotic aortas of neutrophil extracellular trap-deficient mice. Collectively, these data demonstrate that neutrophils can play a key role in the development of the Th17 response in sterile inflammation.

We propose that endogenous G-CSF acts at multiple levels to influence the course of EAU: increasing neutrophil differentiation and production from $\mathrm{BM}$ progenitors, mobilizing neutrophils from the $\mathrm{BM}$ into $\mathrm{PB}$, regulating expression of chemokine receptors on circulating neutrophils, activating endothelial cells to become proadhesive and generate local chemokine gradients, prolonging tissue neutrophil survival, and promoting polarization of the Th17 response. These effects are likely to be enhanced when G-CSF and neutrophil levels increase during inflammation-induced granulopoiesis. As previously highlighted, ${ }^{65}$ neutrophil number and activation status, serum levels of G-CSF, and neutrophil-related chemokines and chemokine receptors may, therefore, provide useful biomarkers in the management of patients with central nervous system autoimmunity. In contrast to decades of elegant work on T-cell-mediated mechanisms, the contribution of neutrophils to the clinical expression of autoimmune diseases, such as uveitis, has received relatively little attention. Careful manipulation of this powerful component of inflammation and autoimmunity may have therapeutic benefits in these conditions.

\section{Acknowledgments}

We thank Ellen Tsui for preparation of histology; Jason Corbin for ADVIA operation; Jaclyn Gilbert Gilbert, Melissa Pritchard, Leanne Scott, Catherine Hay, and Rhiannan Crawley for animal husbandry; Lachlan Whitehead for image analysis; Peter Curwen for technical assistance; and Rhiannon Jones and Emma Stuart for assistance with figure layout and editing. B6;129P2$C s f 3^{\text {tmlArd }} / \mathrm{J}, \quad \mathrm{B} 6.129 \mathrm{X} 1(\mathrm{Cg})-C s f 3 r^{\text {tmlLink }} / \mathrm{J}, \quad \mathrm{C} 57 \mathrm{BL} / 6$ ROR $\gamma \mathrm{T}$-eGFP, and LysM-cre-eGFP mice were kindly provided by Ashley Dunn (Ludwig Institute for Cancer Research, Parkville, VIC, Australia), ${ }^{32}$ Daniel Link (Washington University Medical School, St. Louis, MO), ${ }^{33}$ Gabrielle Belz, and Michael Hickey (Monash University, Clayton, VIC, Australia), respectively.

G.L.G. and A.L.C. designed and performed research, analyzed data, and wrote the manuscript; I.P.W. designed and supervised research and wrote the manuscript; I.K.C., E.S.P., J.M., K.S.-I., and X.C. performed research and analyzed data; P.G.M. and L.L.L. performed research and provided expert advice for both data analysis and manuscript preparation; and E.M. and B.S.M. provided expert advice for both data analysis and manuscript preparation.

\section{Supplemental Data}

Supplemental material for this article can be found at http://dx.doi.org/10.1016/j.ajpath.2015.09.008.

\section{References}

1. Forrester JV: Intermediate and posterior uveitis. Chem Immunol Allergy 2007, 92:228-243

2. Lee RW, Nicholson LB, Sen HN, Chan CC, Wei L, Nussenblatt RB, Dick AD: Autoimmune and autoinflammatory mechanisms in uveitis. Semin Immunopathol 2014, 36:581-594

3. Chen J, Qian H, Horai R, Chan CC, Caspi RR: Mouse models of experimental autoimmune uveitis: comparative analysis of adjuvant- 
induced vs spontaneous models of uveitis. Curr Mol Med 2015, 15: $550-557$

4. Luger D, Silver PB, Tang J, Cua D, Chen Z, Iwakura Y, Bowman EP, Sgambellone NM, Chan CC, Caspi RR: Either a Th17 or a Th1 effector response can drive autoimmunity: conditions of disease induction affect dominant effector category. J Exp Med 2008, 205:799-810

5. Forrester JV, McMenamin PG: Immunopathogenic mechanisms in intraocular inflammation. Chem Immunol 1999, 73:159-185

6. Kerr EC, Raveney BJ, Copland DA, Dick AD, Nicholson LB: Analysis of retinal cellular infiltrate in experimental autoimmune uveoretinitis reveals multiple regulatory cell populations. J Autoimmun 2008, 31:354-361

7. Lieschke GJ, Grail D, Hodgson G, Metcalf D, Stanley E, Cheers C, Fowler KJ, Basu S, Zhan YF, Dunn AR: Mice lacking granulocyte colony-stimulating factor have chronic neutropenia, granulocyte and macrophage progenitor cell deficiency, and impaired neutrophil mobilization. Blood 1994, 84:1737-1746

8. Nakamura H, Ueki Y, Sakito S, Matsumoto K, Yano M, Miyake S, Tominaga T, Tominaga M, Eguchi K: High serum and synovial fluid granulocyte colony stimulating factor (G-CSF) concentrations in patients with rheumatoid arthritis. Clin Exp Rheumatol 2000, 18:713-718

9. Watari K, Ozawa K, Tajika K, Tojo A, Tani K, Kamachi S, Harigaya K, Takahashi T, Sekiguchi S, Nagata S: Production of human granulocyte colony stimulating factor by various kinds of stromal cells in vitro detected by enzyme immunoassay and in situ hybridization. Stem Cells 1994, 12:416-423

10. Panopoulos AD, Watowich SS: Granulocyte colony-stimulating factor: molecular mechanisms of action during steady state and "emergency" hematopoiesis. Cytokine 2008, 42:277-288

11. Boettcher S, Gerosa RC, Radpour R, Bauer J, Ampenberger F, Heikenwalder M, Kopf M, Manz MG: Endothelial cells translate pathogen signals into G-CSF-driven emergency granulopoiesis. Blood 2014, 124:1393-1403

12. Furze RC, Rankin SM: The role of the bone marrow in neutrophil clearance under homeostatic conditions in the mouse. FASEB J 2008 , 22:3111-3119

13. Eash KJ, Greenbaum AM, Gopalan PK, Link DC: CXCR2 and CXCR4 antagonistically regulate neutrophil trafficking from murine bone marrow. J Clin Invest 2010, 120:2423-2431

14. Eash KJ, Means JM, White DW, Link DC: CXCR4 is a key regulator of neutrophil release from the bone marrow under basal and stress granulopoiesis conditions. Blood 2009, 113:4711-4719

15. Broxmeyer HE, Cooper S, Cacalano G, Hague NL, Bailish E, Moore MW: Involvement of Interleukin (IL) 8 receptor in negative regulation of myeloid progenitor cells in vivo: evidence from mice lacking the murine IL-8 receptor homologue. J Exp Med 1996, 184:1825-1832

16. Kohler A, De Filippo K, Hasenberg M, van den Brandt C, Nye E, Hosking MP, Lane TE, Mann L, Ransohoff RM, Hauser AE, Winter O, Schraven B, Geiger H, Hogg N, Gunzer M: G-CSFmediated thrombopoietin release triggers neutrophil motility and mobilization from bone marrow via induction of Cxcr2 ligands. Blood 2011, 117:4349-4357

17. Nguyen-Jackson HT, Li HS, Zhang H, Ohashi E, Watowich SS: GCSF-activated STAT3 enhances production of the chemokine MIP-2 in bone marrow neutrophils. J Leukoc Biol 2012, 92:1215-1225

18. Roilides E, Walsh TJ, Pizzo PA, Rubin M: Granulocyte colonystimulating factor enhances the phagocytic and bactericidal activity of normal and defective human neutrophils. J Infect Dis 1991, 163:579-583

19. Dzhagalov I, St John A, He YW: The antiapoptotic protein Mcl-1 is essential for the survival of neutrophils but not macrophages. Blood 2007, 109:1620-1626

20. Wengner AM, Pitchford SC, Furze RC, Rankin SM: The coordinated action of G-CSF and ELR + CXC chemokines in neutrophil mobilization during acute inflammation. Blood 2008, 111:42-49

21. Yong KL, Linch DC: Differential effects of granulocyte- and granulocyte-macrophage colony-stimulating factors (G- and
GM-CSF) on neutrophil adhesion in vitro and in vivo. Eur J Haematol 1992, 49:251-259

22. Silvescu CI, Sackstein R: G-CSF induces membrane expression of a myeloperoxidase glycovariant that operates as an E-selectin ligand on human myeloid cells. Proc Natl Acad Sci U S A 2014, 111:10696-10701

23. Coppo P, Sibilia J, Maloisel F, Schlageter MH, Voyer AL, GouilleuxGruart V, Goetz J, Desablens B, Tribout B, Lassoued K: Primary Sjogren's syndrome associated agranulocytosis: a benign disorder? Ann Rheum Dis 2003, 62:476-478

24. Kawakami T, Ohashi S, Kawa Y, Takahama H, Ito M, Soma Y, Mizoguchi M: Elevated serum granulocyte colony-stimulating factor levels in patients with active phase of sweet syndrome and patients with active Behcet disease: implication in neutrophil apoptosis dysfunction. Arch Dermatol 2004, 140:570-574

25. Takahama H, Itoh R, Inoue-Komatsu C, Furusawa S, Takahashi H, Mizoguchi M: Granulocyte colony-stimulating factor (G-CSF) and granulocyte macrophage colony-stimulating factor (GM-CSF) in Behcet's disease. J Dermatol 1994, 21:546-552

26. Qiao H, Sonoda KH, Ariyama A, Kuratomi Y, Kawano Y, Ishibashi T: CXCR2 expression on neutrophils is upregulated during the relapsing phase of ocular Behcet disease. Curr Eye Res 2005, 30:195-203

27. Kato Y, Yamamoto T: Serum levels of GRO-alpha are elevated in association with disease activity in patients with Behcet's disease. Int J Dermatol 2012, 51:286-289

28. Valentincic NV, de Groot-Mijnes JD, Kraut A, Korosec P, Hawlina M, Rothova A: Intraocular and serum cytokine profiles in patients with intermediate uveitis. Mol Vis 2011, 17:2003-2010

29. Fraunfelder FW, Harrison D: Peripheral ulcerative keratitis-like findings associated with filgrastim. Cornea 2007, 26:368-369

30. Tsuchiyama J, Imajo K, Sakaguchi N, Yoshino T, Suzaki N, Kondo E, Kawata N, Okada K, Maeda T, Tomiyama Y, Tsubota T: Recurrent idiopathic iridocyclitis after autologous peripheral blood stem-cell transplantation followed by G-CSF administration for acute lymphoblastic leukemia. Ann Hematol 2000, 79:269-271

31. Lawlor KE, Campbell IK, Metcalf D, O'Donnell K, van Nieuwenhuijze A, Roberts AW, Wicks IP: Critical role for granulocyte colony-stimulating factor in inflammatory arthritis. Proc Natl Acad Sci U S A 2004, 101:11398-11403

32. Liu F, Wu HY, Wesselschmidt R, Kornaga T, Link DC: Impaired production and increased apoptosis of neutrophils in granulocyte colonystimulating factor receptor-deficient mice. Immunity 1996, 5:491-501

33. Betsuyaku T, Liu F, Senior RM, Haug JS, Brown EJ, Jones SL, Matsushima K, Link DC: A functional granulocyte colonystimulating factor receptor is required for normal chemoattractantinduced neutrophil activation. J Clin Invest 1999, 103:825-832

34. Mattapallil MJ, Wawrousek EF, Chan CC, Zhao H, Roychoudhury J, Ferguson TA, Caspi RR: The Rd8 mutation of the $\mathrm{Crb} 1$ gene is present in vendor lines of C57BL/6N mice and embryonic stem cells, and confounds ocular induced mutant phenotypes. Invest Ophthalmol Vis Sci 2012, 53: 2921-2927

35. Agarwal RK, Silver PB, Caspi RR: Rodent models of experimental autoimmune uveitis. Methods Mol Biol 2012, 900:443-469

36. Dick AD, Cheng YF, Liversidge J, Forrester JV: Immunomodulation of experimental autoimmune uveoretinitis: a model of tolerance induction with retinal antigens. Eye (Lond) 1994, 8(Pt 1):52-59

37. Xu H, Koch P, Chen M, Lau A, Reid DM, Forrester JV: A clinical grading system for retinal inflammation in the chronic model of experimental autoimmune uveoretinitis using digital fundus images. Exp Eye Res 2008, 87:319-326

38. Carulli G, Mattii L, Azzara A, Brizzi S, Galimberti S, Zucca A, Benedetti E, Petrini M: Actin polymerization in neutrophils from donors of peripheral blood stem cells: divergent effects of glycosylated and nonglycosylated recombinant human granulocyte colonystimulating factor. Am J Hematol 2006, 81:318-323

39. McMillen TS, Heinecke JW, LeBoeuf RC: Expression of human myeloperoxidase by macrophages promotes atherosclerosis in mice. Circulation 2005, 111:2798-2804 
40. Graff G, Gamache DA, Brady MT, Spellman JM, Yanni JM: Improved myeloperoxidase assay for quantitation of neutrophil influx in a rat model of endotoxin-induced uveitis. J Pharmacol Toxicol Methods 1998, 39:169-178

41. Eyles JL, Hickey MJ, Norman MU, Croker BA, Roberts AW, Drake SF, James WG, Metcalf D, Campbell IK, Wicks IP: A key role for G-CSF-induced neutrophil production and trafficking during inflammatory arthritis. Blood 2008, 112:5193-5201

42. Su SB, Grajewski RS, Luger D, Agarwal RK, Silver PB, Tang J, Tuo J, Chan CC, Caspi RR: Altered chemokine profile associated with exacerbated autoimmune pathology under conditions of genetic interferongamma deficiency. Invest Ophthalmol Vis Sci 2007, 48:4616-4625

43. Caspi RR, Chan CC, Fujino Y, Najafian F, Grover S, Hansen CT, Wilder RL: Recruitment of antigen-nonspecific cells plays a pivotal role in the pathogenesis of a $\mathrm{T}$ cell-mediated organ-specific autoimmune disease, experimental autoimmune uveoretinitis. J Neuroimmunol 1993, 47:177-188

44. Ponomarev ED, Shriver LP, Maresz K, Pedras-Vasconcelos J, Verthelyi D, Dittel BN: GM-CSF production by autoreactive T cells is required for the activation of microglial cells and the onset of experimental autoimmune encephalomyelitis. J Immunol 2007, 178:39-48

45. Ito $\mathrm{Y}$, Usui $\mathrm{T}$, Kobayashi $\mathrm{S}$, Iguchi-Hashimoto $\mathrm{M}$, Ito $\mathrm{H}$, Yoshitomi H, Nakamura T, Shimizu M, Kawabata D, Yukawa N, Hashimoto M, Sakaguchi N, Sakaguchi S, Yoshifuji H, Nojima T, Ohmura K, Fujii T, Mimori T: Gamma/delta T cells are the predominant source of interleukin-17 in affected joints in collageninduced arthritis, but not in rheumatoid arthritis. Arthritis Rheum 2009, 60:2294-2303

46. Nian H, Shao H, O’Brien RL, Born WK, Kaplan HJ, Sun D: Activated gammadelta $\mathrm{T}$ cells promote the activation of uveitogenic $\mathrm{T}$ cells and exacerbate EAU development. Invest Ophthalmol Vis Sci 2011, 52:5920-5927

47. Coffelt SB, Kersten K, Doornebal CW, Weiden J, Vrijland K, Hau CS, Verstegen NJ, Ciampricotti M, Hawinkels LJ, Jonkers J, de Visser KE: IL-17-producing gammadelta $\mathrm{T}$ cells and neutrophils conspire to promote breast cancer metastasis. Nature 2015, 522:345-348

48. Mo JS, Matsukawa A, Ohkawara S, Yoshinaga M: CXC chemokine GRO is essential for neutrophil infiltration in LPS-induced uveitis in rabbits. Exp Eye Res 2000, 70:221-226

49. Watts RG, Crispens MA, Howard TH: A quantitative study of the role of F-actin in producing neutrophil shape. Cell Motil Cytoskeleton 1991, 19:159-168

50. Boneberg EM, Hareng L, Gantner F, Wendel A, Hartung T: Human monocytes express functional receptors for granulocyte colonystimulating factor that mediate suppression of monokines and interferon-gamma. Blood 2000, 95:270-276

51. Warnatsch A, Ioannou M, Wang Q, Papayannopoulos V: Inflammation: neutrophil extracellular traps license macrophages for cytokine production in atherosclerosis. Science 2015, 349:316-320

52. Kezic J, McMenamin PG: The monocyte chemokine receptor CX3CR1 does not play a significant role in the pathogenesis of experimental autoimmune uveoretinitis. Invest Ophthalmol Vis Sci 2010, 51:5121-5127

53. Becker MD, O'Rourke LM, Blackman WS, Planck SR, Rosenbaum JT: Reduced leukocyte migration, but normal rolling and arrest, in interleukin-8 receptor homologue knockout mice. Invest Ophthalmol Vis Sci 2000, 41:1812-1817

54. Hashida N, Ohguro N, Nakai K, Kobashi-Hashida M, Hashimoto S, Matsushima K, Tano Y: Microarray analysis of cytokine and chemokine gene expression after prednisolone treatment in murine experimental autoimmune uveoretinitis. Invest Ophthalmol Vis Sci 2005, 46:4224-4234

55. Kojima H, Otani A, Oishi A, Makiyama Y, Nakagawa S, Yoshimura N: Granulocyte colony-stimulating factor attenuates oxidative stress-induced apoptosis in vascular endothelial cells and exhibits functional and morphologic protective effect in oxygeninduced retinopathy. Blood 2011, 117:1091-1100
56. Mei J, Liu Y, Dai N, Hoffmann C, Hudock KM, Zhang P, Guttentag SH, Kolls JK, Oliver PM, Bushman FD, Worthen GS: Cxcr2 and Cxc15 regulate the IL-17/G-CSF axis and neutrophil homeostasis in mice. J Clin Invest 2012, 122:974-986

57. Chuang PI, Yee E, Karsan A, Winn RK, Harlan JM: A1 is a constitutive and inducible Bcl-2 homologue in mature human neutrophils. Biochem Biophys Res Commun 1998, 249:361-365

58. Caspi RR: Th1 and Th2 responses in pathogenesis and regulation of experimental autoimmune uveoretinitis. Int Rev Immunol 2002, 21: 197-208

59. Tarrant TK, Silver PB, Chan CC, Wiggert B, Caspi RR: Endogenous $\mathrm{IL}-12$ is required for induction and expression of experimental autoimmune uveitis. J Immunol 1998, 161:122-127

60. Abi Abdallah DS, Egan CE, Butcher BA, Denkers EY: Mouse neutrophils are professional antigen-presenting cells programmed to instruct Th1 and Th17 T-cell differentiation. Int Immunol 2011, 23: $317-326$

61. McGeachy MJ, Bak-Jensen KS, Chen Y, Tato CM, Blumenschein W, McClanahan T, Cua DJ: TGF-beta and IL-6 drive the production of IL-17 and IL-10 by $\mathrm{T}$ cells and restrain $\mathrm{T}(\mathrm{H})-17$ cell-mediated pathology. Nat Immunol 2007, 8:1390-1397

62. Codarri L, Gyulveszi G, Tosevski V, Hesske L, Fontana A, Magnenat L, Suter T, Becher B: RORgammat drives production of the cytokine GMCSF in helper T cells, which is essential for the effector phase of autoimmune neuroinflammation. Nat Immunol 2011, 12:560-567

63. Hirota K, Duarte JH, Veldhoen M, Hornsby E, Li Y, Cua DJ, Ahlfors H, Wilhelm C, Tolaini M, Menzel U, Garefalaki A, Potocnik AJ, Stockinger B: Fate mapping of IL-17-producing T cells in inflammatory responses. Nat Immunol 2011, 12:255-263

64. Duhen R, Glatigny S, Arbelaez CA, Blair TC, Oukka M, Bettelli E: Cutting edge: the pathogenicity of IFN-gamma-producing Th17 cells is independent of T-bet. J Immunol 2013, 190:4478-4482

65. Rumble JM, Huber AK, Krishnamoorthy G, Srinivasan A, Giles DA, Zhang X, Wang L, Segal BM: Neutrophil-related factors as biomarkers in EAE and MS. J Exp Med 2015, 212:23-35

66. Wesa A, Galy A: Increased production of pro-inflammatory cytokines and enhanced $\mathrm{T}$ cell responses after activation of human dendritic cells with IL-1 and CD40 ligand. BMC Immunol 2002, 3:14

67. Lin AM, Rubin CJ, Khandpur R, Wang JY, Riblett M, Yalavarthi S, Villanueva EC, Shah P, Kaplan MJ, Bruce AT: Mast cells and neutrophils release IL-17 through extracellular trap formation in psoriasis. J Immunol 2011, 187:490-500

68. Pelletier M, Maggi L, Micheletti A, Lazzeri E, Tamassia N, Costantini C, Cosmi L, Lunardi C, Annunziato F, Romagnani S, Cassatella MA: Evidence for a cross-talk between human neutrophils and Th17 cells. Blood 2010, 115:335-343

69. Prendergast RA, Iliff CE, Coskuncan NM, Caspi RR, Sartani G, Tarrant TK, Lutty GA, McLeod DS: T cell traffic and the inflammatory response in experimental autoimmune uveoretinitis. Invest Ophthalmol Vis Sci 1998, 39:754-762

70. McMenamin PG, Crewe J, Morrison S, Holt PG: Immunomorphologic studies of macrophages and MHC class II-positive dendritic cells in the iris and ciliary body of the rat, mouse, and human eye. Invest Ophthalmol Vis Sci 1994, 35:3234-3250

71. Xu H, Dawson R, Forrester JV, Liversidge J: Identification of novel dendritic cell populations in normal mouse retina. Invest Ophthalmol Vis Sci 2007, 48:1701-1710

72. McMenamin PG: Dendritic cells and macrophages in the uveal tract of the normal mouse eye. Br J Ophthalmol 1999, 83 598-604

73. Carlson T, Kroenke M, Rao P, Lane TE, Segal B: The Th17-ELR+ CXC chemokine pathway is essential for the development of central nervous system autoimmune disease. J Exp Med 2008, 205:811-823

74. Weber FC, Nemeth T, Csepregi JZ, Dudeck A, Roers A, Ozsvari B, Oswald E, Puskas LG, Jakob T, Mocsai A, Martin SF: Neutrophils are required for both the sensitization and elicitation phase of contact hypersensitivity. J Exp Med 2015, 212:15-22 